\title{
Characterization of spermatogonial markers in the mature testis of the dogfish (Scyliorhinus canicula L.)
}

\author{
Adrien Bosseboeuf ${ }^{1,2,3,4}$, Aude Gautier ${ }^{1,2,3}$, Pierrick Auvray ${ }^{4}$, Sylvie Mazan ${ }^{5}$ and \\ Pascal Sourdaine $e^{1,2,3}$ \\ ${ }^{1}$ Normandie University, Caen, France, ${ }^{2}$ UCBN, BioMEA, F-14032 Caen, France, ${ }^{3}$ CNRS INEE FRE3484, F-14032 \\ Caen, France, ${ }^{4}$ KELIA; Group CELLIS PHARMA, Parc Technopolitain Atalante Saint Malo, 35400 Saint Malo, France \\ and ${ }^{5}$ Développement et Evolution des Vertébrés, UMR 7150 CNRS and Université Pierre et Marie Curie-Paris 6, \\ Station Biologique de Roscoff, Roscoff, France
}

Correspondence should be addressed to P Sourdaine at Normandie University; Email: pascal.sourdaine@unicaen.fr

A Bosseboeuf and A Gautier contributed equally to this work

\begin{abstract}
In dogfish, spermatogenesis progresses from a restricted germinative zone, which lines the dorsal testicular vessel. Single spermatogonia $\left(A_{s}\right)$, including the spermatogonial stem cells (SSCs), produce successively paired ( $\left.A_{p}\right)$, undifferentiated $\left(A_{u 4}\right.$ to $\left.A_{u 512}\right)$, and differentiated $\left(A_{d 1}\right.$ to $\left.A_{d 8}\right)$ spermatogonia and preleptotene $(P L)$ spermatocytes through 13 mitoses. Dogfish spermatogonial subpopulations present classical morphological characteristics but cannot be distinguished on the basis of molecular markers. This characterization has been initiated in mammals despite the difficulty to separate each spermatogonial subpopulation. For instance, both glial cell-derived neurotrophic factor family receptor alpha 1 (GFR $\alpha 1)$ and promyelocytic leukemia zinc finger protein (PLZF) are markers of undifferentiated spermatogonia, whereas receptor tyrosine kinase C-kit is a marker of differentiated spermatogonia. The aim of this study is to characterize spermatogonial markers and to differentiate several spermatogonial subpopulations. Dogfish cDNA sequences have been identified and validated by phylogenetic analyses for gfr 1 , plzf, pou2, as well as for high-mobility group box proteins 2 and 3 ( $h m g b 2$ and 3) and for mini-chromosome maintenance protein 6 ( $\mathrm{mcm6})$. We have used the anatomical advantage of the polarized dogfish testis to analyze the expression of those markers by RT-PCR and in situ hybridization. gfr $\alpha$, pou2, and plzf have been detected in the testicular germinative zone, suggesting that spermatogonial markers are relatively well conserved among vertebrates but with a less restricted expression for plzf. Moreover, $\mathbf{h m g b 3}$ and $\mathbf{m c m} 6$ have been identified as new markers of differentiated spermatogonia. Finally, this first molecular characterization of spermatogonial subpopulations in a chondrichthyan model will be useful for further studies on the SSC niche evolution.
\end{abstract}

Reproduction (2014) 147 125-139

\section{Introduction}

Spermatogenesis is a highly conserved process that makes long-term male fertility possible, thanks to continuous production of spermatozoa from spermatogonial stem cells (SSCs). The future of SSCs is controlled by specific regulating factors in a closed microenvironment called niche, first described by Schofield (1983). In Drosophila, the niche controls SSC self-renewal or differentiation commitment by four different mechanisms: symmetric and asymmetric division, reversion of engaged spermatogonia, and SSC loss (Sheng \& Matunis 2011). Symmetric and asymmetric divisions have also been reported in mammals (Oatley \& Brinster 2008), as well as reversion by intercellular bridge rupture (Nakagawa et al. 2010, Yoshida 2012). In the rodent niche, single spermatogonia ( $A_{s}$ including SSCs) proliferate to form paired spermatogonia $\left(A_{p}\right)$, aligned and undifferentiated spermatogonia $\left(A_{a \mid 4-16}\right)$, differentiated spermatogonia (A to B), and spermatocytes (De Rooij \& Russell 2000, Oatley \& Brinster 2008).

In vertebrates and invertebrates, conserved SSC characteristics such as low mitotic activity, mottled chromatin, and contact with the basal membrane have been described for mammals (De Rooij \& Russell 2000, Chiarini-Garcia et al. 2003), zebrafish (Leal et al. 2009), dogfish (Loppion et al. 2008), and Drosophila (Joti et al. 2011, Sheng \& Matunis 2011). In mammals, the molecular characterization of the different spermatogonial subpopulations is in progress and a few markers have been characterized. The glial cell-derived neurotrophic factor (GDNF), identified as the main SSC self-renewal control factor, is secreted by the Sertoli cells and binds to the GDNF family receptor alpha 1 (GFR $\alpha 1$ ), 
expressed by spermatogonia, and signals through the Ret receptor tyrosine kinase (RET; Naughton et al. 2005, Oatley \& Brinster 2008). Additional cell surface markers of undifferentiated spermatogonia have been identified, such as thymus antigen 1 (THY1; Kubota et al. 2004). Transcriptional factors promyelocytic leukemia zinc finger protein (PLZF) and Pou domain class 5 homeobox 1 (POU5F1) are other important factors involved in regulating SSCs fate in mammals (Buaas et al. 2004, Tenenhaus Dann et al. 2008) as they promote their selfrenewal and stimulate the expression of pluripotency factors like REDD1 (Hobbs et al. 2010). On the other hand, some factors such as the tyrosine kinase receptor C-KIT or the spermatogenesis- and oogenesis-specific basic helix-loop-helix protein 1 and 2 (SOHLH1/2) are known to promote the proliferation and differentiation of spermatogonial progenitors (Feng et al. 2000, Ballow et al. 2006, Prabhu et al. 2006). Such markers have been used to establish a molecular signature of different spermatogonial subpopulations previously identified on the basis of their morphology (Chiarini-Garcia et al. 2003, Hermann et al. 2010). Thus, mouse undifferentiated spermatogonia $A_{s}, A_{p}$ and $A_{a l}$ are GFR $\alpha 1^{+}$, $\mathrm{PLZF}^{+} / \mathrm{C}-\mathrm{KIT}^{-}$and differentiating spermatogonia $\mathrm{A}$ and $\mathrm{B}$ are $\mathrm{GFR} \alpha 1^{-} / \mathrm{PLZF}^{-} / \mathrm{C}-\mathrm{KIT}^{+}$. Even if the relationship between the molecular signature of undifferentiated spermatogonia and their self-renewing activity remains to be further clarified, GFR $\alpha 1^{+} / \mathrm{Nanos}^{+}$spermatogonial populations are known to largely correspond to $A_{s}$ and $A_{p}$ spermatogonia, which are potential stem cells in the undisturbed testis. Next, these cells give rise to transient amplifying Neurog $3^{+}$Aal spermatogonia, which differentiate to $\mathrm{Kit}^{+} \mathrm{A} 1$ spermatogonia (for review: Yoshida (2012)). However, undifferentiated mouse spermatogonia exhibit internal heterogeneity in expression of genes or in behavior (Yoshida 2012). Characterization of the different subpopulations of undifferentiated spermatogonia and of their microenvironment remains to be improved.

The anatomy of the dogfish testis makes it an interesting model to study the microenvironment controlling spermatogenesis. Furthermore, spermatogenesis has been well described and is divided into 18 stages (Stanley 1966, Holstein 1969, Loir \& Sourdaine 1994, Loir et al. 1995). Spermatogenesis proceeds within spermatocysts (cysts) where germ cell development is synchronous. Cysts are composed of spermatoblasts (480-500 per cyst) in which one Sertoli cell is associated with one spermatogonium initially and with 64 spermatids in the post-meiotic stages. Cysts are formed after a proliferating phase for both spermatogonia and Sertoli precursors upon leaving the germinative zone constituting the potential stem cell compartment (Loppion et al. 2008), and cysts then proceed in maturational order toward the opposite margin of the gonad. Zonation thus allows to observe all spermatogenesis stages on a cross section of the testis and to dissect the pre-meiotic state (zone $\mathrm{A}$, stages $\mathrm{I}-\mathrm{VI}$ ), meiotic state (zone $\mathrm{B}$, stages $\mathrm{VII}-\mathrm{X}$ ), early spermiogenesis (zone $C$, stages XI and XII), and late spermiogenesis (zone D, stages XIII-VVII) regions (Loir \& Sourdaine 1994, Loir et al. 1995). Zone A can be further dissected to separate the area A0, which corresponds to the germinative zone (stage I) and the remaining area, A- . This area corresponds to the progenitor proliferating area (stage II), the cyst formation (stage IIla) coinciding with the end of Sertoli cell divisions (Stanley 1966, Holstein 1969, Loppion et al. 2008), and to the further four mitosis of differentiated spermatogonia leading to preleptotene (PL) spermatocytes (stages IIIb, IV, V, and VI). In this model, the number of spermatogonial divisions from stage I to stage VI was estimated to be 13 by Holstein (1969) on the basis of the number of spermatoblasts per cyst. Our previous observations (Loppion et al. 2008) have suggested that the germinative zone located between the testicular capsule and the main testicular blood vessel contains single spermatogonia, paired spermatogonia, and (at least) clusters of four interconnected spermatogonia. Therefore, undifferentiated spermatogonia were found to be distributed from stage I (germinative zone) to stage II, which could correspond to the successive types of $A_{s}, A_{p}$, and $A_{a l}$ described for rodents. Moreover, the phylogenetic position of Chondrichthyans, the progress in sequence database production for several elasmobranchs (Coolen et al. 2007, Venkatesh et al. 2007, King et al. 2011, Tan et al. 2012, Quan et al. 2013), and the possibility to perform transcriptome (Redon et al. 2010) and proteome (Loppion et al. 2010) analyses makes the dogfish an excellent reference species to study and understand the evolution of the SSC niche.

The aim of this study is to improve the molecular characterization of spermatogonial subpopulations in dogfish. This characterization includes mammalian established markers such as GFR $\alpha 1$, POU5F1, and PLZF and dogfish previously highlighted sequences (Redon et al. 2010) such as mini-chromosome maintenance protein $6(\mathrm{mcm} 6)$ and the high-mobility group box proteins 2 and 3 (hmgb2 and hmgb3). Phylogenetic analysis, real-time PCR, and in situ hybridization experiments were performed and allowed us to show that gfr 1 , pou5f1, and plzf are expressed in the SSC niche of the dogfish testis, but with differences in their expression patterns compared with mammals, and that $h m g b 2$ and $m c m 6$ are potential markers to discriminate potential SSCs from differentiating spermatogonia.

\section{Materials and methods}

\section{Animals}

Mature male dogfish Scyliorhinus canicula were captured from Cherbourg (English channel, France) using the facilities of the Lycée Maritime et Aquacole and stored in natural seawater 
tanks at the Centre de Recherches en Environnement Côtier (Luc-sur-Mer, France). The fish were allowed to acclimate for at least 2 weeks before tissue sampling and were killed by severing the spinal cord and pithing (except when brain was collected). Testes, brain, kidney, eye, muscle, spleen, epididymis, liver, gill, and epigonal organ (the lymphomyeloid tissue of elasmobranchs) were sampled and directly transferred into ice-cold Tri-Reagent with the exception of the testes that were transferred into ice-cold Gautron's buffer (Loir \& Sourdaine 1994) complemented with $58 \mathrm{mM}$ TMAO. Fresh testicular cross sections were arrayed into five zones (A0, A-, B, C, and D) under a stereomicroscope, as described previously (Loir \& Sourdaine 1994).

\section{Identification and in silico analyses of dogfish sequences}

Sequences of interest were obtained from a dogfish testicular suppressive and subtractive cDNA bank (Redon et al. 2010), from a dogfish embryonic and juvenile cDNA bank (Redon et al. 2010, Quan et al. 2013), and from a dogfish gonadic RNA sequencing bank (ANR PhyloFish project currently ongoing) using the TBLASTN algorithm. Phylogenetic analyses were performed using additional amino acid sequences selected by means of the TBLASTN algorithm from ESTs, mRNA, or genome databases from the NCBI Institute (accession numbers are indicated in Fig. 1). Amino acid sequences were aligned using the MUltiple Sequence Comparison by Log-Expectation (MUSCLE) Software (http://www.ebi.ac.uk/Tools/msa/muscle/) and then shortened to exclude divergent extremities. Phylogenetic trees were built using the Molecular Evolutionary Genetics Analysis (MEGA) package version 5.1 (Tamura et al. 2011) and two methods (maximum likelihood and neighborjoining methods). The reliability of the inferred trees was estimated by applying the bootstrap procedure with 1000 replications. Protein domains were subsequently identified and annotated by means of the Simple Modular Architecture Research Tool (SMART) Software version 7 (http://smart.emblheidelberg.de/; Schultz et al. (1998) and Letunic et al. (2012)). The conservation of protein domains between the dogfish and other species (mice, chicken, xenopus, and zebrafish) was assessed with ClustalW Multiple alignment version 1.4 (Thompson et al. 1994) and is indicated as a percentage of identity in Fig. 1.

\section{RNA extraction and purification}

Fresh tissue samples $(100 \mathrm{mg})$ were ground up, total mRNA were extracted in $1 \mathrm{ml}$ Tri-Reagent with conical pestles and needles, complemented with $200 \mu \mathrm{l}$ 1-bromo-3-chloropropane (Sigma), and homogenized and centrifuged for $15 \mathrm{~min}$ at $4{ }^{\circ} \mathrm{C}$ at $13500 \mathrm{~g}$. Aqueous phases were transferred to new tubes with $500 \mu$ l isopropanol, centrifuged, and pellets were rinsed with $75 \%$ ethanol and air-dried. Total RNA were re-suspended in DEPC-treated water and quantified with a Nanodrop 2000 spectrophotometer (Thermo Scientific, Les Ulis Courtaboeuf, France). All glassware and solutions containing RNA were RNase free.

\section{Real-time PCR}

To prevent any DNA contamination, $1 \mu \mathrm{g}$ total RNA was treated with $2 \cup$ RQ1 DNase (Promega) in a $10 \mu \mathrm{l}$ volume. Random hexamers (250 ng) were added and total RNA was denatured for 5 min at $70{ }^{\circ} \mathrm{C}$ and then RT was immediately carried out for $1 \mathrm{~h}$ at $37^{\circ} \mathrm{C}$ with $500 \mathrm{nM}$ dNTP, $25 \mathrm{U}$ RNasin, $200 \mathrm{U}$ M-MLVRT, and M-MLV RT buffer (Promega) in a final $25 \mu \mathrm{l}$ volume. Real-time PCR was performed on an iCycler apparatus (BioRad) in triplicate and repeated using CDNA from three or six different animals. Real-time PCR consisted of $5 \mu \mathrm{l} 1 / 20$ diluted cDNA, $70 \mathrm{nM}$ primers, and Absolute Blue SYBR Green Fluorescein mix (Thermo Scientific) with the following cycling parameters: $1 \times\left(95^{\circ} \mathrm{C}, 30 \mathrm{~s}\right) ; 45 \times\left(\left(95^{\circ} \mathrm{C}, 30 \mathrm{~s}\right)\right.$ and $\left(60{ }^{\circ} \mathrm{C}\right.$, $45 \mathrm{~s}))$; and $80 \times\left(55+1{ }^{\circ} \mathrm{C}, 10 \mathrm{~s}\right)$. Results were established with the iCycler Software (IQ ${ }^{\mathrm{TH}} 3.1$ Bio-Rad), efficiency of PCR was assessed using appropriate dilutions series, and single amplicon formation was confirmed on melting curves. cDNA results were normalized against 5S RNA by means of the comparative $C t$ method (Livak \& Schmittgen 2001). The use of this reference gene has been validated previously (Redon et al. 2010). Significant statistical groups ( $a, b, c$, and $d ; P<0.05$ between each) were created using the Mann-Whitney $U$ test, and relative expression results were shown by mean \pm S.E.M.

\section{In situ hybridization}

Dig-conjugated riboprobes were synthesized from cDNA clones. cDNA synthesis was carried out through a standard PCR procedure with specific primers (Table 1) and then cloning was performed using the T/A Cloning kit (Clontech) and electrocompetent TOP10 Escherichia coli. Plasmids were purified with the DNA Miniprep purification kit (Promega), and riboprobe cDNA matrix was generated by M13 PCR on 100 ng plasmid with $1 \mathrm{mM} \mathrm{MgCl} 2,0.2 \mathrm{mM}$ of each dNTPs, $0.4 \mu \mathrm{M} \mathrm{M} 13$ primer, and $0.625 \cup$ Go Taq DNA Polymerase. The cycling parameters were as follows: $1 \times\left(95^{\circ} \mathrm{C}, 2 \mathrm{~min}\right), 35 \times\left(\left(95^{\circ} \mathrm{C}, 45 \mathrm{~s}\right)\right.$ and $\left(50{ }^{\circ} \mathrm{C}\right.$, $\left.1 \mathrm{~min})\left(72^{\circ} \mathrm{C}, 2 \mathrm{~min}\right)\right)$, and $1 \times\left(72{ }^{\circ} \mathrm{C}, 5 \mathrm{~min}\right)$. PCR products were subsequently purified through precipitation. Their size was checked by gel migration and in vitro transcription was carried out for $1 \mathrm{~h}$ at $37^{\circ} \mathrm{C}$ on $2 \mu \mathrm{g}$ purified PCR product with $40 \mathrm{U}$ RNAsin, $25 \cup$ T7 or SP6 polymerase, $10 \mathrm{mM}$ dithiothreitol, $1 \mathrm{mM}$ rATP/rCTP and rGTP, $0.65 \mathrm{mM}$ rUTP, and $0.35 \mathrm{mM}$ digoxigeninUTP (Roche). The riboprobes were purified by precipitation, ethanol washed, quantified using a Nanodrop 2000 spectrophotometer (Thermo Scientific), and their quality checked by migration (Bioanalyzer 2100, Agilent, Waldbronn, Germany).

Testicular slices, $2 \mathrm{~mm}$ thick, were fixed in ice-cold $4 \%$ paraformaldehyde ( $\mathrm{w} / \mathrm{v}$ in PBS) for $24 \mathrm{~h}$, then progressively dehydrated in a series of $\mathrm{PBS} /$ methanol mixtures at staggered concentration levels (100\%/0\%; 75\%/25\%; 50\%/50\%; $25 \% / 75 \%$; and $0 \% / 100 \%$ ), and stored at $-20{ }^{\circ} \mathrm{C}$. Before mounting, the testis slices were progressively rehydrated in PBS and cryoprotected for $12 \mathrm{~h}$ at $4{ }^{\circ} \mathrm{C}$ in a $30 \% / 70 \%$ sucrose/PBS solution. Testis slices were embedded in OCT compound (VWR), frozen on carbonic ice for $20 \mathrm{~min}$, and stored at $-80^{\circ} \mathrm{C}$. Eight to $12 \mu \mathrm{m}$-thick cryosections were cut at $-20^{\circ} \mathrm{C}$ with a cryotome (cryocut 1800, Leica), mounted on Superfrost slides (Thermo Scientific), and directly subjected to hybridization as follows. 

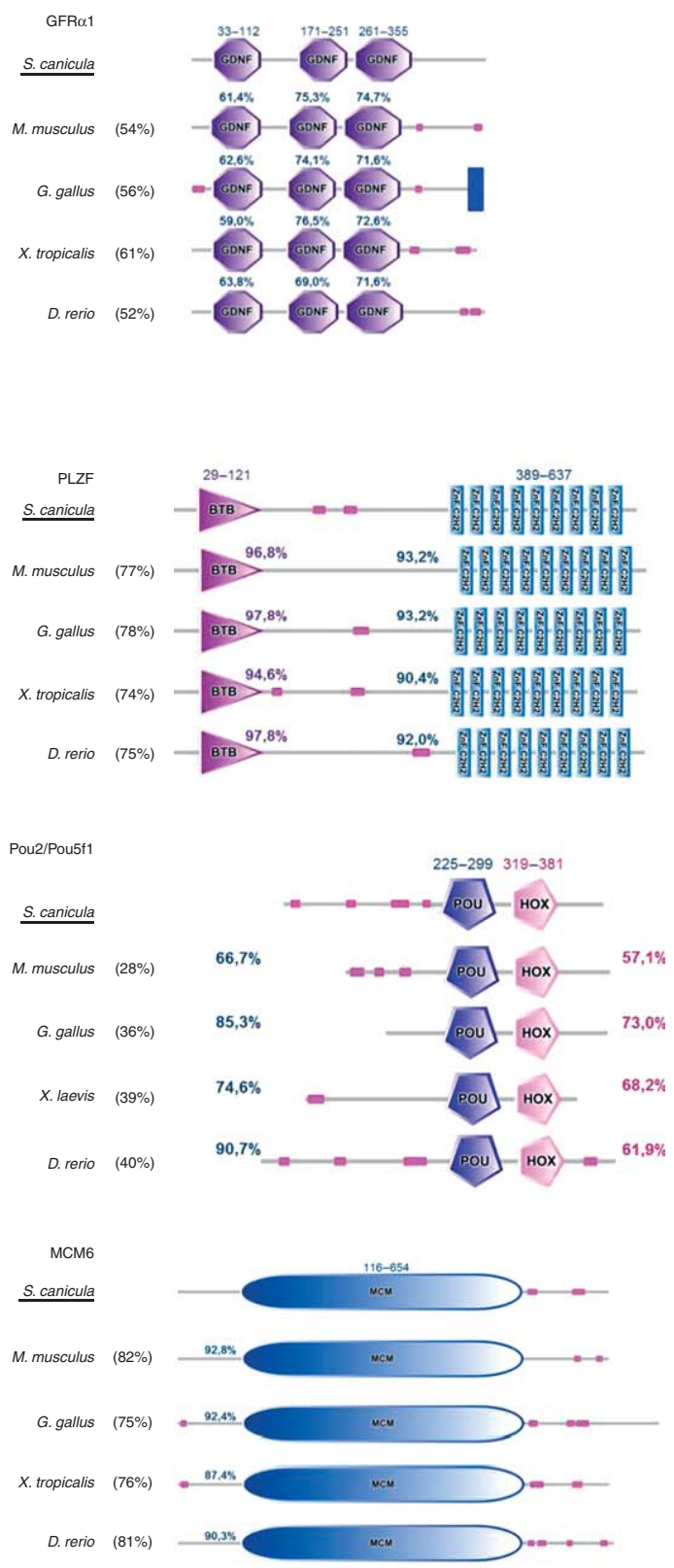

HMGB2/3

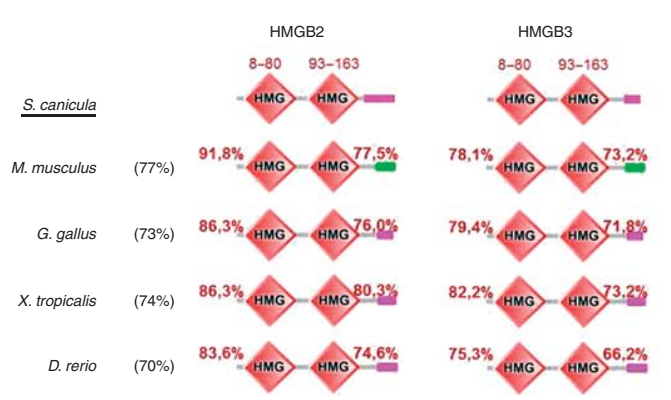

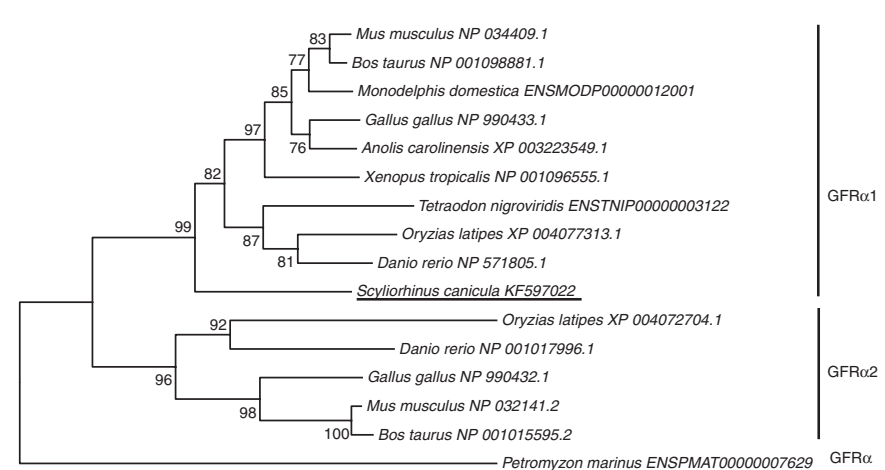
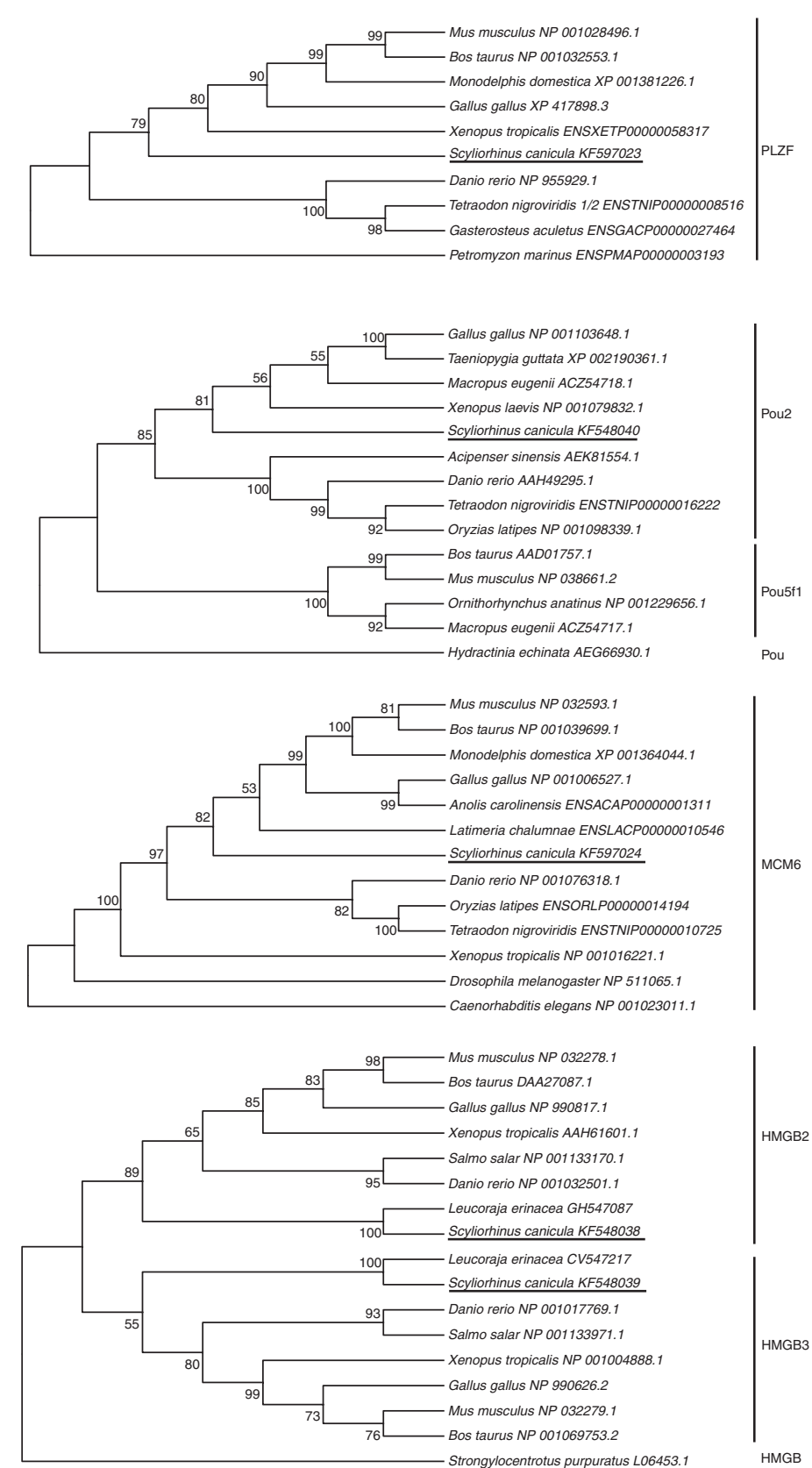
Hybridizations with sense and antisense RNA probes were performed in parallel. Sections were rinsed in PBS, fixed for $10 \mathrm{~min}$ in 4\% PFA solution, washed in PBS, and treated at room temperature for $4 \mathrm{~min}$ with $5 \mu \mathrm{g} / \mathrm{ml}$ proteinase $\mathrm{K}$ (Roche) in $0.05 \mathrm{M}$ Tris and $0.01 \mathrm{M}$ EDTA, $\mathrm{pH}$ 8. Sections were then washed in PBS; fixed for 10 min with 4\% PFA; and washed and acetylated for $10 \mathrm{~min}$ in $100 \mathrm{mM}$ tri-ethanolamine, $0.25 \%$ anhydride acid solution, followed by 5 min in $100 \mathrm{mM}$ Tris, $\mathrm{pH} 8,100 \mathrm{mM}$ glycine solution. After one PBS wash, sections were washed for $5 \mathrm{~min}$ with $150 \mathrm{mM} \mathrm{NaCl}$ and directly incubated overnight at $65{ }^{\circ} \mathrm{C}$ with $500 \mathrm{ng}$ of probes (previously denatured for $5 \mathrm{~min}$ at $\left.75{ }^{\circ} \mathrm{C}\right)$ in the hybridization mixture $(50 \%$ de-ionized formamide, $2 \times$ SSC, $5 \mathrm{mM}$ EDTA, $\mathrm{pH} 8,0.1 \%$ Tween 20, Denhardt's solution, $10 \%$ dextran sulfate, $0.1 \mathrm{mg} / \mathrm{ml}$ heparin, $0.1 \%$ Chaps, $0.5 \mathrm{mg} / \mathrm{ml}$ tRNA, and complemented with DEPC-treated water). After hybridization, sections were washed at $65^{\circ} \mathrm{C}$ in $1 \times \mathrm{SSC}$ and $1.5 \times \mathrm{SSC}$, for $10 \mathrm{~min}$ each, followed by two 20 -min washes at $37^{\circ} \mathrm{C}$ with $2 \times$ SSC. Sections were then incubated for $30 \mathrm{~min}$ with $0.2 \mu \mathrm{g} / \mathrm{ml}$ RNase $\mathrm{A}$ in $2 \times \mathrm{SSC}$ at $37^{\circ} \mathrm{C}$ before another $2 \times$ SSC wash, followed by two 30-min incubations at $60{ }^{\circ} \mathrm{C}$ with $0.2 \times$ SSC. After two 15-min MABT washes (0.1 M maleic acid, $150 \mathrm{mM} \mathrm{NaCl}$, and $0.1 \%$ Tween 20 in DEPC-treated water, $\mathrm{pH}$ 7.5) at room temperature, sections were incubated for $3 \mathrm{~h}$ at room temperature with the blocking solution $(2 \%$ blocking reagent, $20 \%$ decomplemented sheep serum, and MABT in DEPCtreated water). Immediately after this step, anti-DIG antibody coupled with alkaline phosphatase (Roche) diluted at a 1:2000 ratio in the blocking solution was added to the slides and incubated overnight at $4{ }^{\circ} \mathrm{C}$. Unbound antibodies were removed through eight washes with MABT for 5-30 min at room temperature. Pre-revelation treatment was performed in an NTMT solution $(100 \mathrm{mM} \mathrm{NaCl}, 100 \mathrm{mM}$ Tris, pH 9.5, $50 \mathrm{mM} \mathrm{MgCl}_{2}$, and $0.1 \%$ Tween 20 in DEPC-treated water) and revealing was done by addition of NBT-BCIP (Roche) on the sections for a few minutes or a few hours until staining could be visually detected. Sections were finally washed in PBS and mounted with Mowiol medium (1.5 $\mu \mathrm{M}$ Mowiol 4-88, $1.3 \mathrm{mM}$ glycerol, $0.15 \mathrm{M}$ Tris- $\mathrm{HCl}, \mathrm{pH} 8.5$, and $33 \% \mathrm{H}_{2} \mathrm{O}$ ).

For histology, paraffin sections of formaldehyde-fixed tissues were stained with hematoxylin, eosin, and green light and mounted with roti-histol. All observations and analyses were performed using a Nikon eclipse 80i microscope and Nikon NIS-Elements D 3.0 Software. As expected, none of the sense riboprobes gave any signal (Supplementary Figure 1, see section on supplementary data given at the end of this article).

\section{Results}

\section{Identification of dogfish orthologs of spermatogonial expressed sequences}

The candidate genes selected for this study have two origins: gfra1, plzf, and pou2/pou5f1 encode for classical markers of undifferentiated spermatogonia based on bibliographical references, and mcm6 and hmgb3 were shown to be over-expressed in the spermatogonial zone of the dogfish testis in our previous suppression subtractive hybridization study. As the genome of the dogfish $S$. canicula has not yet been sequenced, TBLASTN blasts were performed on three different dogfish cDNA banks: a testicular suppressive and subtractive cDNA library, an embryonic and juvenile cDNA bank, and a testicular and ovarian RNA sequencing bank. The complete cDNA sequences of candidates were successfully identified, and the accession numbers are indicated in Fig. 1. The global homology of the translated sequences was rather high for Plzf, Mcm6, Hmgb2, and Hmgb3 (>70\%) but much lower for Pou2/Pou5f1, and Gfra 1 (30-60\%). Protein sequences were then analyzed using the SMART Software in order to identify the protein domains. For all candidates, these domains showed a high conservation level with an identity between dogfish and other species sequences usually around 70-100\% (Fig. 1). A phylogenetic analysis was performed to validate the orthologous relationship of dogfish sequences with the genes of interest and to establish their evolutionary relationships. In the rooted phylogenetic trees, dogfish sequences always segregated with the expected orthologous genes. Concerning Pou2/Pou5f1, the sequence presented a glutamic acid residue in the $\mathrm{POU}$ domain in spite of the presence of an aspartic acid in Pou5f1 orthologs. It also lacked the arginine deletion specific to Pou5f1 orthologs. Therefore, the corresponding protein segregated with Pou2. Globally, dogfish sequences were found, either at the root of the gnathostomata (Hmgb3 and Gfra1), which is a position consistent with current hypotheses on species evolution, or at the root of the Osteichthyes (Plzf, Mcm6, and Hmgb2), a position that could be explained by the derivation of teleostean fish sequences after an additional genome duplication.

\footnotetext{
Figure 1 Protein domain identification and conservation and phylogenetic analysis. Dogfish sequences of interest (gfra 1, plzf, pou2, mcm6, hmgb2, and $h m g b 3$ ) were obtained from several cDNA banks and their identities were validated by additional in silico analyses. For each sequence of interest, protein domains were identified using the SMART v7 Software. The global homology (in brackets) and the homology of protein domain sequences (on top of the related boxes) were determined between dogfish and other species sequences (mice, chicken, xenopus, and zebrafish) using BioEdit Software. All protein domains present in Osteichthyes were found to be well conserved in dogfish. Phylogenetic trees were built using the MUSCLE Alignment Software and the MEGA v5.1 Software. Trees were constructed using the maximum likelihood and neighbor-joining methods but only the latter is represented. The reliability of the inferred trees was estimated using the bootstrap method over 1000 replications. Phylogenetic trees were rooted with agnatha or non-vertebrate sequences. Dogfish sequences segregated with proteins coded by their orthologs at the root of gnathostomata as expected, or between fish and tetrapods, a position that could be explained by the specific evolution of the teleostean genomes.
} 
Table 1 Nucleotide sequences of the primers used for real-time PCR and riboprobe synthesis. Primer sequences and PCR product sizes are indicated for each gene. As referenced in the table, the cDNA library previously established by Redon et al. (2010) was used with M13Fwd/Rev primers to produce riboprobes for in situ hybridization.

\begin{tabular}{|c|c|c|c|c|c|}
\hline $\begin{array}{l}\text { Experimental } \\
\text { procedure }\end{array}$ & $\begin{array}{l}\text { Gene } \\
\text { name }\end{array}$ & $\begin{array}{l}\text { GenBank } \\
\text { accession } \\
\text { number }\end{array}$ & Primer name & Primer sequence $\left(5^{\prime}-3^{\prime}\right)$ & $\begin{array}{c}\text { PCR product } \\
\text { size }(\mathrm{bp})\end{array}$ \\
\hline \multirow{14}{*}{ RT-PCR } & \multirow[t]{2}{*}{$5 S$ rRNA } & \multirow{2}{*}{ M24954.1 } & Sc_5S rRNA_1q & TCGTCTGATCTCGGAAGCTA & \multirow[t]{2}{*}{85} \\
\hline & & & Sc_5SrRNA_1Aq & AGCCTACTGCACCTGGTATTC & \\
\hline & \multirow[t]{2}{*}{ gfr $\alpha 1$} & \multirow[t]{2}{*}{ KF597022 } & Sc_GFR $\alpha \_1 \mathrm{q}$ & ACCGGTGACCTGGCCTGTAGCA & \multirow[t]{2}{*}{131} \\
\hline & & & Sc_GFR $\alpha \_1 A q$ & GGGCTCTGTTGGACCACCTCCA & \\
\hline & \multirow[t]{2}{*}{ plzf } & \multirow{2}{*}{ KF597023 } & Sc_Plzf_Q-F1' & AGACTTTCCAGCAGATTCTCGA & \multirow[t]{2}{*}{155} \\
\hline & & & Sc_Plzf_Q-R1 & ATCTGTTGCCTGAATTGTCT & \\
\hline & \multirow{2}{*}{ pou2 } & \multirow{2}{*}{ KF548040 } & Sc_Pou5f_qF2 & GAAGCCCACCAGTGAAGAAA & \multirow[t]{2}{*}{99} \\
\hline & & & Sc_Pou5f_gR2 & TТССССТТСТGССТССТАТТ & \\
\hline & \multirow[t]{2}{*}{ hmgb2 } & \multirow[t]{2}{*}{ KF548038 } & Sc_HMGB2_qF1 & TCAAGAGCGAGTCTCCTGGA & \multirow[t]{2}{*}{123} \\
\hline & & & Sc_HMGB2_qR1 & TCTCCTTTAACCGGGATGC & \\
\hline & \multirow[t]{2}{*}{ hmgb3 } & \multirow{2}{*}{ KF548039 } & Sc_HMGB3_1q & AAGCCGTTCATTAGCAAAGC & \multirow[t]{2}{*}{102} \\
\hline & & & Sc_HMGB3_1Aq & AGGGGGCTTCTTTGCACTAT & \\
\hline & \multirow{2}{*}{ mcm6 } & \multirow[t]{2}{*}{ KF597024 } & Sc_MCM6_1q & GATTGAACTGAAGCAGACTGG & \multirow[t]{2}{*}{78} \\
\hline & & & Sc_MCM6_1Aq & ACAAGGAAGGGATCCTGCTC & \\
\hline \multirow[t]{5}{*}{ ISH } & \multirow[t]{2}{*}{ gfr $\alpha 1$} & \multirow[t]{2}{*}{ KF597020 } & M13 Fwd31 & CAGTCACGACGTTGTAAAACGACGGCCAGTG & \multirow[t]{2}{*}{755} \\
\hline & & & M13 Rev33 & CAGGAAACAGCTATGACCATGATTACGCCAAGC & \\
\hline & $\begin{array}{l}\text { pou2/ } \\
\text { pou5f1 }\end{array}$ & KF597021 & & & 804 \\
\hline & hmgb3 & GT916248 & & & 529 \\
\hline & mcm6 & GT916249 & & & 497 \\
\hline
\end{tabular}

\section{Conserved and new factors are expressed in the proliferative area of the mature dogfish testis}

The expression pattern of identified transcripts was assessed by real-time PCR in a large panel of tissue samples (brain, spleen, kidney, epididymis, muscle, eye, liver, epigonal tissue, gill, and testis) to assess their tissue distribution, and in the five testicular zones corresponding to the germinative zone $(\mathrm{A} 0)$, the differentiating spermatogonial zone (A-), the meiotic zone (B), the early spermatids zone (C), and the late spermatids zone (D), in order to assess their stage-specific expression during spermatogenesis (Fig. 2). The gfra 1 mRNA was predominantly detected in brain and testis tissue comparatively to other tissue types, with an mRNA relative abundance eight times higher in brain than in testis material (Fig. 2A). During spermatogenesis, gfr 1 was significantly more expressed in the germinative zone (A0) than in the A- zone containing differentiating spermatogonia and almost undetectable in spermatocyte- and spermatid-related zones (Fig. $2 \mathrm{~A}^{\prime}$ ). The plzf mRNA was predominantly expressed in the liver and eye compared with other tissues (Fig. 2B). In testis, plzf expression was significantly higher in the germinative zone (A0) than in the differentiating zone (A-) and presented a persistent level of expression in more advanced stages (Fig. 2 $\mathrm{B}^{\prime}$ ). Both hmgb2 and hmgb3 showed a large distribution of expression in the observed tissues (Fig. 2C and D). In the testis, hmgb2 and hmgb3 were more highly expressed in the germinative and spermatogonial differentiation zones than in the meiosis and spermiogenesis zones (Fig. $2 \mathrm{C}^{\prime}$ and $\mathrm{D}^{\prime}$ ). The mcm6 gene shows a preferential expression in testis, around tenfold higher than in the other tissues (Fig. 2E).
An equivalent expression level was detected between areas $\mathrm{A} 0$ and $\mathrm{A}$ - and the expression gradually decreased during the progress of spermatogenesis (Fig. 2E'). In summary, gfr 1 and $p l z f$ were preferentially expressed in the germinative area, while hmgb2, hmgb3, and mcm6 appeared preferentially expressed throughout the whole spermatogonial zone of the mature dogfish testis.

\section{Stages of spermatogonia in the dogfish}

Spermatogonia were classified according to their number of mitoses and their progress from the germinative zone to the cyst at stage $\mathrm{VI}$ in order to precisely define spermatogonial stages on the basis of types described in rodents (i.e., $A_{s}, A_{p}$, and $A_{a l}$ ) (Figs 3, 4A, $B, C, D, E$, and F and 5A, B, C, D, and E). Considering that the formation of cysts, completed at stage IIla, coincides with the end of Sertoli cell divisions and the start of the synchronous proliferation of spermatogonia, differentiating spermatogonia can be subdivided into stages IIIa, IIIb, IV, V, and VI (the last stage corresponding to PL spermatocytes) and named $A_{d 1}, A_{d 2}, A_{d 4}, A_{d 8}$, and PL respectively. Consequently, undifferentiated stage I (germinative zone) and stage II (in and outside of the germinative zone) spermatogonia can be subdivided into stages $A_{s}, A_{p}, A_{u 4}, A_{u 8}$, and so on up to stage $A_{u 512}$ in order to take into account the following: i) the theoretical number of spermatoblasts per cyst; ii) the fact that spermatogonia are interconnected after their first division; and iii) the lack of division between the late $A_{a l}$ spermatogonium and the $A_{1}$ spermatogonium in rodents. As illustrated in Figs 3, 4, and 5, large single spermatogonia (Figs $4 \mathrm{~A}$ and $5 \mathrm{~A}$ ) were observed in the 


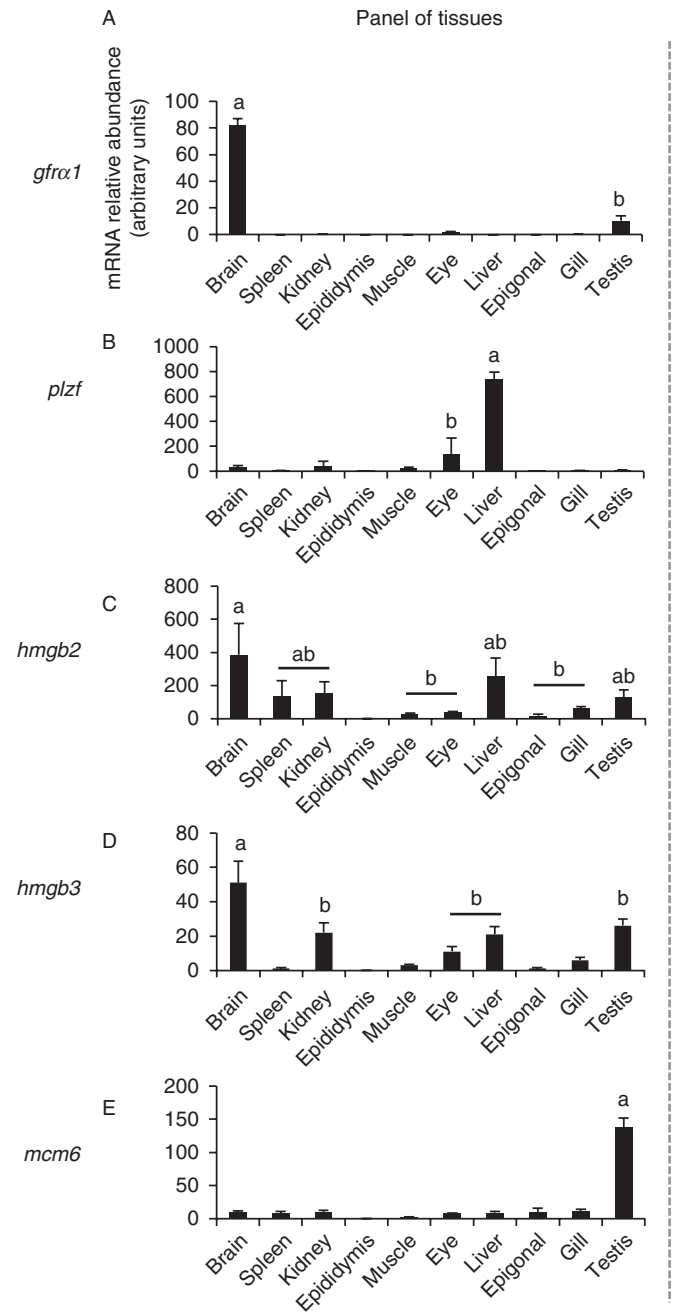

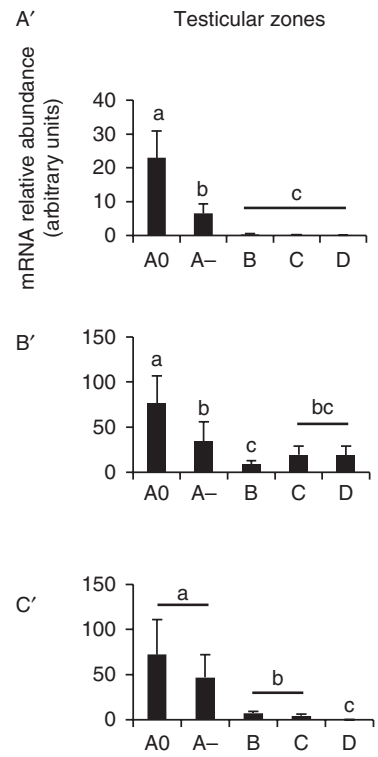

$D^{\prime}$
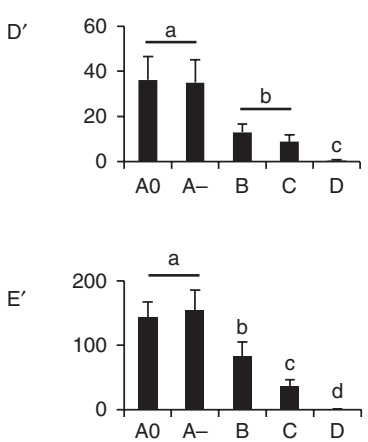

Figure 2 Classical and new factors are preferentially expressed in the spermatogonial area of the dogfish testis. Relative abundance of mRNAs was measured by RT-PCR and normalized with 5 S rRNA (gfr 1 , plzf, hmgb2, hmgb3, and mcm6) in a large panel of tissue types (A, B, C, D, and $\mathrm{E}$ ) and in the five testicular zones $\left(A^{\prime}, B^{\prime}, C^{\prime}, D^{\prime}\right.$, and $\left.E^{\prime}\right)$. Tissue samples were brain, spleen, kidney, epididymis, muscle, eye, liver, epigonal tissue, gill, and the testicular zone A. Testicular zones were as follows: A0, germinative zone; $A-$, spermatogonial proliferative and differentiation zone; B, meiotic zone; C, spermatids zone; and $\mathrm{D}$, spermiogenesis, spermiation, and cyst resorption zone. Statistical analysis was performed using MannWhitney $U$ test with $P$ value $<0.05$ between each statistical groups $\mathrm{a}, \mathrm{b}, \mathrm{C}$, and $\mathrm{d}$. $\mathrm{A}, \mathrm{B}, \mathrm{C}, \mathrm{D}$, and $\mathrm{E}$ : from three animals in duplicates $(N=3 ; n=6) ; \mathrm{A}^{\prime}, \mathrm{B}^{\prime}, \mathrm{C}^{\prime}$, $\mathrm{D}^{\prime}$, and $\mathrm{E}^{\prime}$ : from six animals in duplicates $(N=6$; $n=12$ ). germinative zone as well as paired spermatogonia and four-spermatogonia clusters. Upon leaving the germinative zone along a defined path (Fig. $3 \mathrm{~B}$ and $\mathrm{C}$ ), both spermatogonia and Sertoli cells proliferate and associate with each other to form clusters (stage Ila, Fig. 4B) and, progressively, spherical cysts without lumen (stage IIb, Fig. 4C). In stage Ilc, spermatogonia and Sertoli cells are arranged in a single layer around the lumen (Fig. 4D). Stage III cysts correspond to cysts that have a single layer of Sertoli cell nuclei around the central lumen (stage Illa, Figs $4 \mathrm{E}$ and $5 \mathrm{C}$ ) and one or two layers of differentiating spermatogonia towards the basal lamina (stage IIlb, Fig. 5D). At stage IIla, one spermatogonium is associated with one Sertoli cell per spermatoblast. At stage IIIb, two spermatogonia are associated with one Sertoli cell per spermatoblast. Stage IV shows four layers of spermatogonia corresponding to four spermatogonia per spermatoblast, and Sertoli cell nuclei remains at the adluminal position (Fig. 4F). Stage $V$ presents five layers of spermatogonia, corresponding to eight spermatogonia per spermatoblast, and Sertoli cell nuclei are in an adluminal (majority) or intermediate position (Fig. 5E).
Stage VI exhibits about six layers of germ cells (corresponding to $16 \mathrm{PL}$ spermatocytes per spermatoblast) and Sertoli cell nuclei are in an intermediate (majority) or basal position. In cysts containing primary spermatocytes, Sertoli cell nuclei were in basal position (Fig. 5F).

\section{Pou 2 and gfr $\alpha 1$ are preferentially expressed in the germinative zone of the mature dogfish testis}

In situ hybridization was performed on slices of adult testicular tissue, and representative results for genes, preferentially expressed in the germinative zone, were shown from stage I to IV to detail gene expression pattern from the SSC niche (stage I; Fig. 4A), the progenitors transition (stages Ila-Ilc; Fig. 4B, C, and D), and the spermatogonial differentiation way (stages IIIa-IV; Fig. 4E and F). The pou2 transcript was detected in the nucleus and cytoplasm of single spermatogonia, of one-paired spermatogonia (Fig. $4 \mathrm{~A}^{\prime}$ ), and of undifferentiated spermatogonia in stage Ila (Fig. $4 \mathrm{~B}^{\prime}$ ). In stages IIb and Ilc, the staining seems to be mostly cytoplasmic and of variable intensity depending on the spermatogonia (Fig. $4 C^{\prime}$ and $D^{\prime}$ ). 


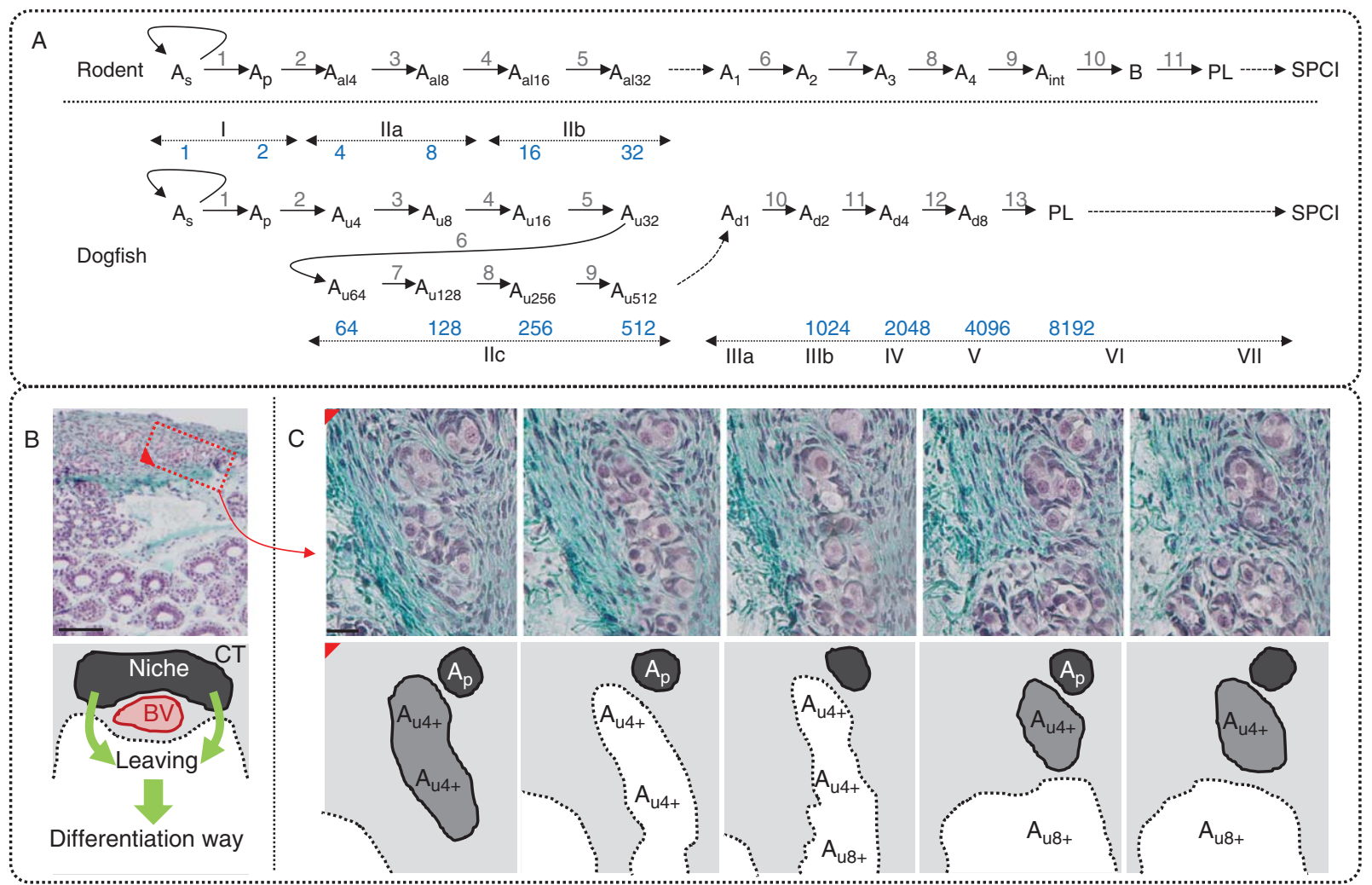

Figure 3 Spermatogonial classification and stem cell niche in the dogfish testis. Comparison of the spermatogonial classification between rodents and dogfish. (A) The different spermatogonial subpopulations in rodents are single $\left(A_{s}\right)$, paired $\left(A_{p}\right)$, aligned $\left(A_{a l 4-32}\right)$, and differentiated $\left(A_{1-4}, A_{\text {int }}\right.$ and B) (Oatley \& Brinster 2008). The spermatogonial subpopulations between stages I and VII in the dogfish are single $\left(A_{s}\right)$, paired $\left(A_{p}\right)$, undifferentiated ( $A_{44-512}$ corresponding to rodent $\left.A_{a l}\right)$, and differentiated spermatogonia $\left(A_{d 1-8}\right)$, and PL correspond to preleptotene spermatocytes. Blue numbers represent the estimated number of germ cells and each mitosis step, defined by Holstein (1969), was represented by gray numbers. Histology and schemes of the testicular zone A of the dogfish (B) include distinct parts: the germinative niche (black), the connective tissue (light gray), and the differentiation compartment (white). Serial histological study of the stem cell compartment showed that germinal cells leave the niche on either side the main blood vessel ( $B$ and $C$ ) along spans of connective tissue (C). $A_{p}, A_{u 4+}$, and $A_{u 8+}$ spermatogonia represented paired, 4,8 (or more) undifferentiated spermatogonia respectively. ct, connective tissue; bv, blood vessel. Scale bars: $100 \mu \mathrm{m}$ (B), $20 \mu \mathrm{m}$ (C).

Pou2 was no longer expressed in stage IIla (Fig. 4E'), in more advanced spermatogonial stages (Fig. $4 \mathrm{~F}^{\prime}$ ) and in later stages of spermatogenesis (Supplementary Figure 1B). Somatic cells have shown no expression of pou2 except the adluminal edge of the Sertoli cells in stages IIc and IIla

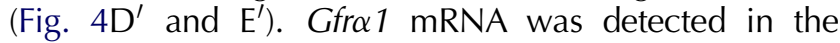
cytoplasm of single and paired spermatogonia (Fig. $4 \mathrm{~A}^{\prime \prime}$ ), of cluster of progenitors in stages Ila, Ilb, and Ilc (Fig. 4B", $\mathrm{C}^{\prime \prime}$, and $\mathrm{D}^{\prime \prime}$ respectively) and of spermatogonia in stage Illa (Fig. 4E"). No expression was detected in more advanced spermatogonia (Fig. $4 \mathrm{~F}^{\prime \prime}$ ) or in later spermatogenesis stages (Supplementary Figure 1C). Sense riboprobes showed no labeling (Supplementary Figure 1). In summary, ISH experiments confirmed that pou 2 and gfra 1 were preferentially expressed in undifferentiated spermatogonia.

\section{plzf is expressed from the SSCs niche to the early spermiogenesis area of the mature dogfish testis}

In situ hybridization of plzf was illustrated with wider pictures in order to highlight its large expression pattern. Indeed, plzf was detected in germinal cells from stage I (undifferentiated spermatogonia) to stage $\mathrm{XI}$ (young spermatids) (Fig. $6 \mathrm{~A}^{\prime}, \mathrm{B}^{\prime}, \mathrm{C}^{\prime}$, and $\mathrm{D}^{\prime}$ ). Besides, this staining seems to gradually decrease from undifferentiated spermatogonia to spermatids. Plzf was found in the nucleus and cytoplasm of spermatogonia (Fig. $6 \mathrm{~A}^{\prime}$ and $\mathrm{B}^{\prime}$ ), and in the nucleus of spermatocytes and spermatids (Fig. $6 \mathrm{~B}^{\prime}, \mathrm{C}^{\prime}$, and $\mathrm{D}^{\prime}$ ). The somatic cells composing the connective tissue of the niche were also stained at a lower intensity (Fig. 6A'). Finally, Sertoli cells from stage I to stage III (Fig. $6 \mathrm{~A}^{\prime}$ and $\mathrm{B}^{\prime}$ ) seem to be stained as well as spermatogonia.

\section{hmgb3 and $\mathrm{mcm} 6$ are preferentially expressed in differentiated spermatogonia of the mature dogfish testis}

Histology and ISH were illustrated at the early stages I and II (Fig. 5A and B) and during the whole period of active proliferation of spermatogonia from stage IIla (Fig. 5C) to primary spermatocytes in stage VII (Fig. 5F). hmgb3 mRNA was not detected in single and paired spermatogonia but clusters of $\mathrm{A}_{\mathrm{u} 4}$ spermatogonia 


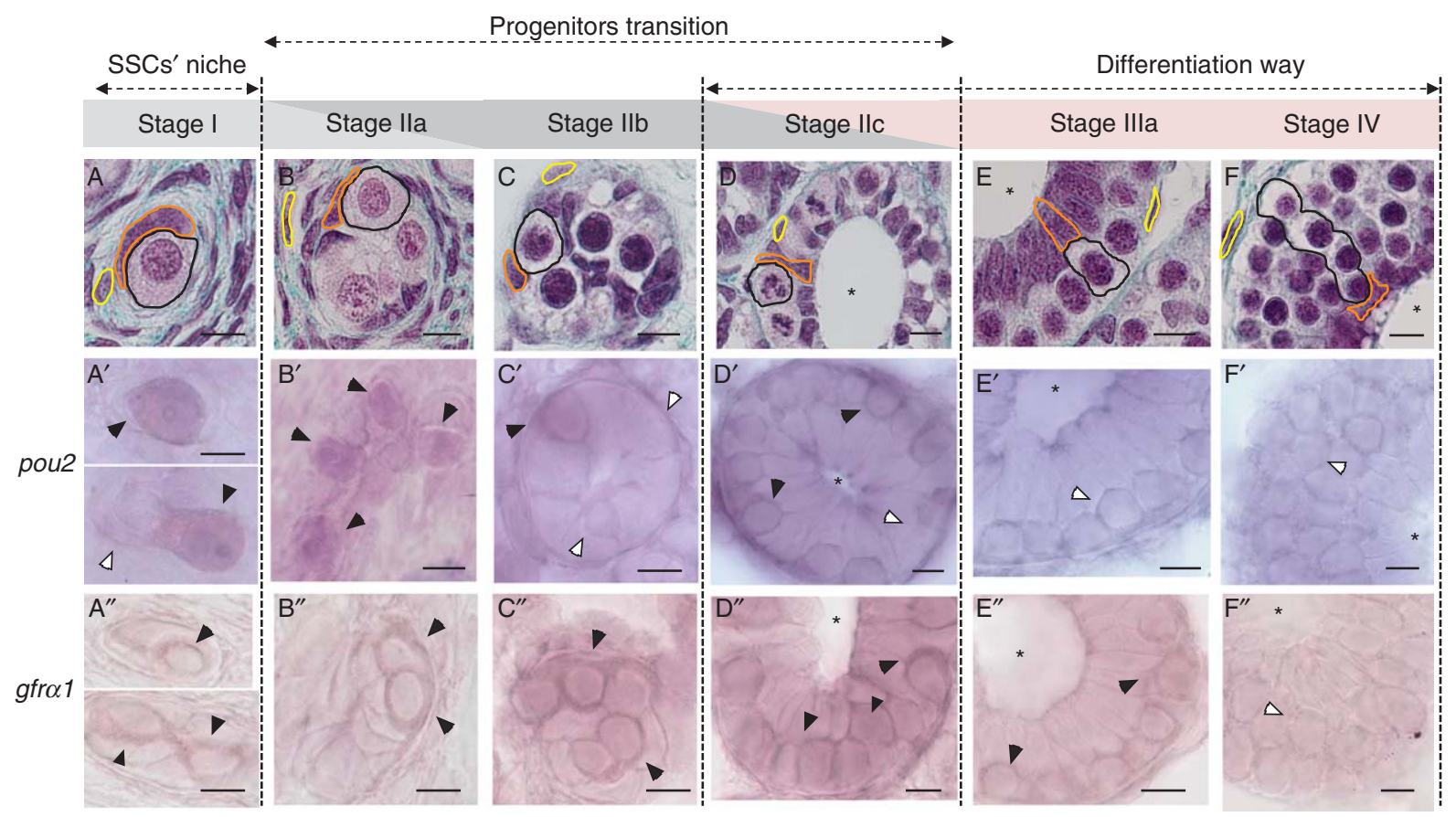

Figure 4 gfr 1 and pou 2 showed early expression, in the germinative area and during progenitor transition. Histology of spermatogonial stages in S. canicula (A, B, C, D, E, and F): spermatogonia (black circle), Sertoli cell nuclei (orange circle), pericystic cell nuclei (yellow circle), and cyst lumen (asterisks), see Results section for description of stages. In situ hybridization on testicular sections with antisense digoxigenin-conjugated riboprobes directed against pou2 transcript $\left(\mathrm{A}^{\prime}, \mathrm{B}^{\prime}, \mathrm{C}^{\prime}, \mathrm{D}^{\prime}, \mathrm{E}^{\prime}\right.$, and $\left.\mathrm{F}^{\prime}\right)$ or gfr 1 transcript $\left(\mathrm{A}^{\prime \prime}, \mathrm{B}^{\prime \prime}, \mathrm{C}^{\prime \prime}, \mathrm{D}^{\prime \prime}, \mathrm{E}^{\prime \prime}\right.$, and $\left.\mathrm{F}^{\prime \prime}\right)$. Black arrowheads, stained spermatogonia; white arrowheads, unstained spermatogonia. Scale bars: $10 \mu \mathrm{m}$.

showed cytoplasmic labeling (Fig. 5A'). In stages IIc, IIIa, $\mathrm{IIIb}$, and through to stage $\mathrm{V}$, all spermatogonia presented hmgb3 mRNA in their cytoplasm (Fig. 5B', $\mathrm{C}^{\prime}, \mathrm{D}^{\prime}$, and $\mathrm{E}^{\prime}$ respectively). At stage VII, all primary spermatocytes were comparatively unlabeled (Fig. $5 \mathrm{~F}^{\prime}$ ) like later stages (Supplementary Figure 1E). The mcm6 mRNA was not detected in single and paired spermatogonia (Fig. 5A") but was present in the cytoplasm of spermatogonial progenitors (stage IIc, Fig. 5B") and of differentiating spermatogonia (stage IIla, Fig. 5C"; stage IIIb, Fig. 5D") up to stage $\mathrm{V}$ (Fig. $5 \mathrm{E}^{\prime \prime}$ ). At stage VII, no primary spermatocytes expressed hmgb3 (Fig. 5F") like more advanced stages of spermatogenesis (Supplementary Figure 1F). In summary, the ISH results showed that hmgb3 and mcm6 were preferentially expressed in proliferating and differentiating spermatogonia.

\section{Discussion}

\section{POU2/POU5F1 and GFR $\alpha 1$ are highly conserved SSCs markers}

The duplication event that gave rise to the pou 2 and pou5f1 genes was first positioned early in the tetrapod's evolution (Frankenberg et al. 2010), but new genomic data now available for the spiny dogfish and the little skate seem to position this duplication at least in the gnathostomes ancestor (Frankenberg \& Renfree 2013).
In the dogfish, the identification of a single-class $\mathrm{V}$ POU family member, which segregates with Pou2 rather than with Pou5f1 on the basis of two previously described Pou2-specific sequence signatures (Frankenberg \& Renfree 2013), was consistent with the first hypothesis. A synteny analysis would confirm this orthology relationship, but unfortunately the genome of the dogfish is not available yet. In the new Pou2/Pou5f1 hypothesis, Pou5f1 would be extinct in the lesser spotted dogfish, as it is assumed to be in the elephant fish lineage but retained in some rays and sharks. Both Pou2 and Pou5f1 (Oct4) show the feature of induction of pluripotency (Tapia et al. 2012). In testis, Pou2/Pou5f1 is an important marker of pluripotency for the spermatogonial lineage and was involved in the stem cell fate maintenance (Tenenhaus Dann et al. 2008). Pou2/Pou5f1 expression was reported in primordial germ cells during development and in undifferentiated spermatogonia in adults from medaka to mammals, although some differences in the expression patterns were noticed between species (Bhartiya et al. 2010, Sanchez-Sanchez et al. 2010, Wu et al. 2010, Encinas et al. 2012). In our study, pou2/ pou5f1 transcript was detected in both cytoplasm and nuclei of single and paired spermatogonia, in the cytoplasm of undifferentiated spermatogonia until the cystic formation coinciding with the onset of spermatogonial differentiation and their synchronous 


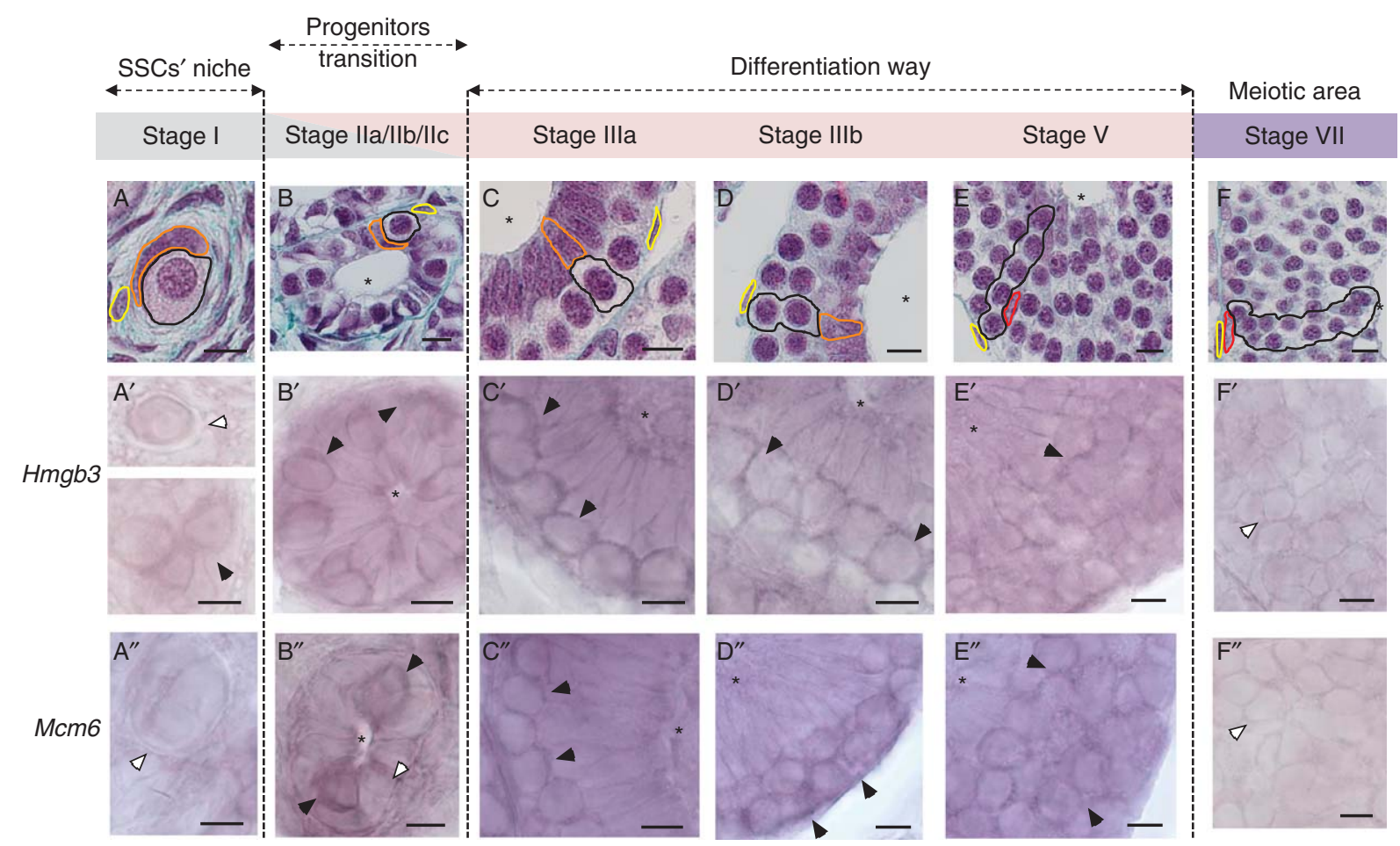

Figure $5 \mathrm{hmgh} 3$ and $\mathrm{mcm} 6$ showed a late expression during progenitors' transition and spermatogonial differentiation. Histology of spermatogonial and meiotic stages in S. canicula (A, B, C, D, E, and F): germ cells (black circle), Sertoli cell nuclei (orange circle), migrating Sertoli cell nuclei (red circle), and cyst lumen (asterisks), see Results section for description of stages. In situ hybridization on testicular sections with antisense digoxigeninconjugated riboprobes directed against $h m g b 3$ transcript $\left(\mathrm{A}^{\prime}, \mathrm{B}^{\prime}, \mathrm{C}^{\prime}, \mathrm{D}^{\prime}, \mathrm{E}^{\prime}\right.$, and $\left.\mathrm{F}^{\prime}\right)$ or mcm6 transcript $\left(\mathrm{A}^{\prime \prime}, \mathrm{B}^{\prime \prime}, \mathrm{C}^{\prime \prime}, \mathrm{D}^{\prime \prime}, \mathrm{E}^{\prime \prime}\right.$, and $\left.\mathrm{F}^{\prime \prime}\right)$. Black arrowheads, stained spermatogonia; white arrowheads, unstained spermatogonia. Scale bars: $10 \mu \mathrm{m}$.

proliferation. These results suggest that the role of Pou2/ Pouf5f1 in SSCs' maintenance could be conserved along the vertebrates' evolution process. Additionally, the firsttime observation of an asymmetrical distribution of pou2 mRNA in one of two paired spermatogonia strongly suggests an asymmetric division of SSCs leading them to a different functional state in the dogfish, as described in Drosophila and mammals (Oatley \& Brinster 2008, Sheng \& Matunis 2011).

In dogfish, gfr 1 transcripts were mainly detected in testis and brain. In brain, it has been reported that GFR $\alpha 1$ was involved in the self-renewal process of neural stem cells, a function conserved from zebrafish to mammals (Airaksinen et al. 2006). As the highest expression level of gfr 1 was found in dogfish brain, we can hypothesize a similar function in $S$. canicula. In testis cells, GFR $\alpha 1$ was reported to be a marker of undifferentiated spermatogonia in many mammalian models (Suzuki et al. 2009, Costa et al. 2012). GFR $\alpha 1$ and its co-receptor RET stimulate SSC self-renewal in response to the GDNF (Naughton et al. 2005). A recent study in Nile tilapia provides the first characterization of Gfr $\alpha 1$ expression pattern in testis of a teleostean fish with an expression restricted to undifferentiated spermatogonia (Lacerda et al. 2013). Similarly, gfr 1 mRNA was located in undifferentiated spermatogonia of the dogfish, but this expression was extended, at a lower level, to early differentiating spermatogonia, and such extended expression pattern was also described in monkey (Hermann et al. 2010). Although the Gfra1 ligand, Gdnf, has not yet been characterized in the $S$. canicula databanks, these first results suggest that Gfra1 may control the self-renewal of SSCs in our chondrichthyan model. Furthermore, in our model, Gfra $1+$ spermatognia are not restricted to the germinative area (the potential SSC niche) and undifferentiated spermatogonia expressed Gfr $\alpha 1$ until completion of the cyst formation (stage IIla) and presence of differentiated spermatogonia. Considering that Gfr $\alpha 1+$ undifferentiated spermatogonia are potential real stem cells, that proportions of Aal spermatogonia are $\mathrm{Gfr} \alpha 1^{+}$, that resultant single spermatogonia after fragmentation of syncytial spermatogonia could be used to replenish the stem cell pool in mice (Yoshida 2012), and the results obtained in this study, there appears to be a clear need to achieve a better understanding of the behavior of Gfra1-positive cells in the SSC system.

\section{plzf is a germinal marker conserved in dogfish but with a larger kinetic of expression}

$p l z f$ is a transcriptional factor involved in the maintenance of the undifferentiating statement of spermatogonia by repressing the expression of the differentiating factor 


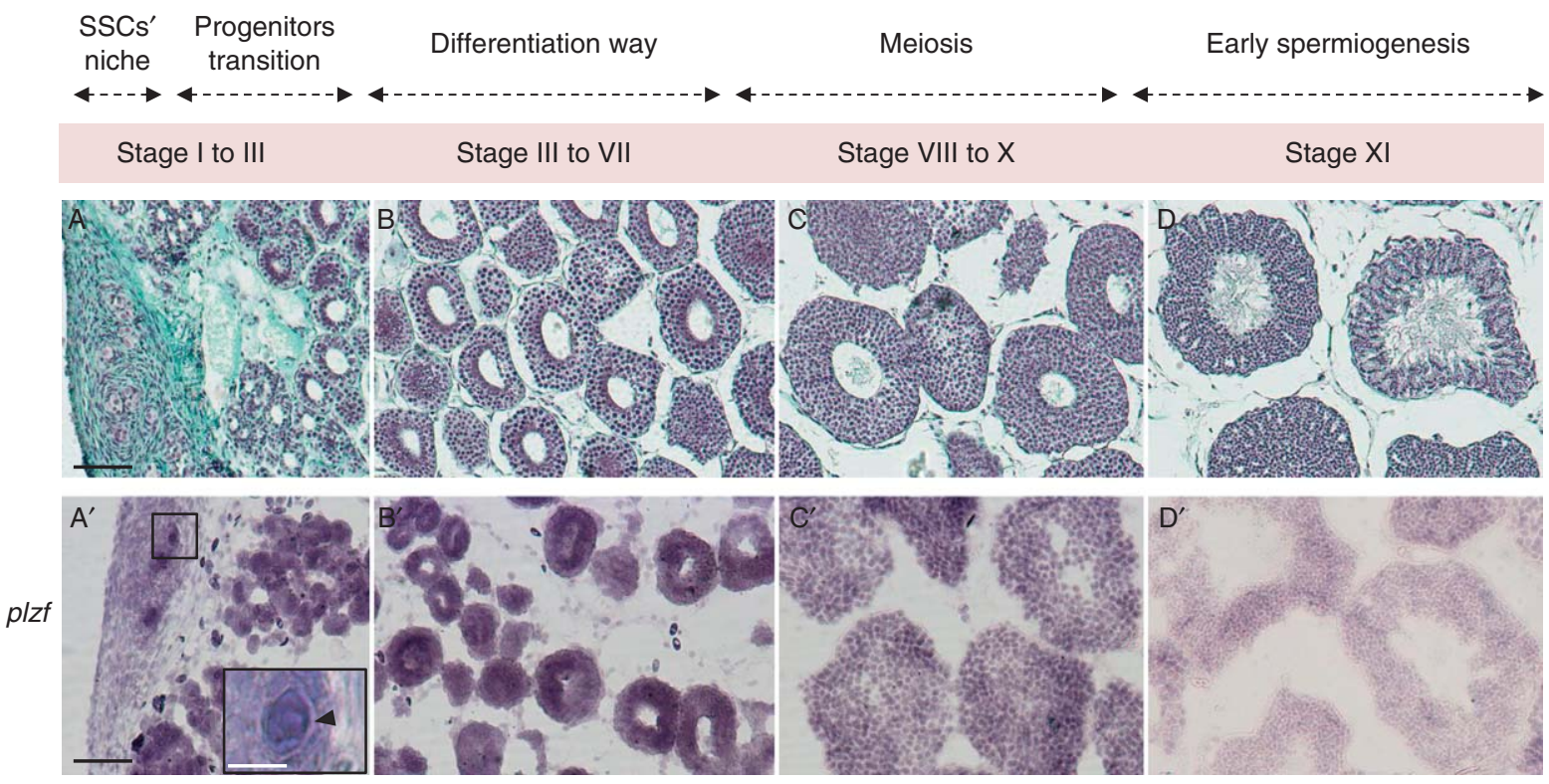

Figure 6 Plzf showed a large expression pattern from the niche to the spermatids area. Histology of the niche (A), spermatogonial stages (B), meiotic stages (C), and early spermiogenesis stages (D) in S. canicula. In situ hybridization on testicular sections with antisense digoxigenin-conjugated riboprobes directed against plzf transcript $\left(\mathrm{A}^{\prime}, \mathrm{B}^{\prime}, \mathrm{C}^{\prime}\right.$, and $\left.\mathrm{D}^{\prime}\right)$. Inset in $\mathrm{A}^{\prime}$ showed stained single spermatogonia (black arrowhead) in the niche. Sertoli cells seem to be also stained from stage I to stage III ( $\mathrm{A}^{\prime}$ and $\left.\mathrm{B}^{\prime}\right)$. Black and white scale bars represented 100 and $20 \mu \mathrm{m}$ respectively.

C-KIT and by repressing the mTORC1 inhibition of GDNF signaling (Buaas et al. 2004, Filipponi et al. 2007, Hobbs et al. 2010). Sequence analyses have shown that PLZF is highly conserved, from dogfish to mammals. Tissue expression studies have shown that PLZF is expressed in testis of different species such as the carp (Mohapatra et al. 2010) and the mouse (Kokkinaki et al. 2010), as observed in the dogfish, even if its expression was higher in the liver and eye than in the testis. In dogfish, plzf was detected not only in undifferentiated spermatogonia, in agreement with observations in various mammals and in zebrafish (Hermann et al. 2009, Kokkinaki et al. 2010, Ozaki et al. 2011, Costa et al. 2012), but also in differentiated spermatogonia, a larger expression pattern also described in humans and monkeys (Hermann et al. 2009). Surprisingly, plzf expression in dogfish meiotic germ cells and young spermatids was a unique case in the studied species. Moreover, plzf transcripts were detected in dogfish Sertoli cells from stage I to stage III. This may be explained by the fact that in dogfish, those cells actively proliferate until complete cyst formation, which occurs at stage IIla (Stanley 1966, Holstein 1969, Loppion et al. 2008). These data suggest that PLZF may have a main conserved function in stem cell fate regulation in vertebrates. However, the significance of its expression in differentiating spermatogonia in some species and in meiotic germ cells and proliferating Sertoli cells in dogfish remains to be explored.

\section{hmgb2, hmgb3, and mcm6 are new factors expressed in the spermatogonial compartment of the mature dogfish}

Members of the Hmgb family are highly conserved DNA-binding proteins capable of interacting with various proteins that regulate transcription, chromatin dynamics, immune response, development, and other cellular processes in several species (Moleri et al. 2010, Malarkey \& Churchill 2012). Hmgb1 and 2 were detected in fathead minnow mature testes (Martyniuka \& Alvarez 2013). In addition to this, HMGB4 was found in adult mice testes. In mice, HMGB1 is ubiquitously expressed at high levels in lymphoid tissues and in testes where its expression in Sertoli cells and germ cells is associated with a potential antibacterial role (Zetterstrom et al. 2006). HMGB2 expression is mostly restricted to lymphoid organs and testes, especially in spermatocytes and $H m g b 2^{-1-}$ mice, have defective spermatogenesis (Ronfani et al. 2001). HMGB3 was defined as a proliferative marker of hematopoietic stem cells (Nemeth et al. 2006). HMGB4 is preferentially expressed in adult mouse testis and is located in spermatocytes and spermatids (Catena et al. 2009). In dogfish, hmgb2 and hmgb3 were detected in tissue from several organs, contrasting with the tissue specificity observed in adult mice. Both genes are expressed in testis tissue, which is in agreement with the results observed in mice for Hmgb2 but not for Hmgb3. A preferential expression was observed in spermatogonia rather than in spermatocytes. On the other hand, hmgb3 transcripts 
were not observed by ISH in the dogfish epigonal tissue, which is the chondrichthyan hematopoietic tissue. These results suggest a diverging evolution of $\mathrm{HMGB}$ functions between chondrichthyans and mammals. However, $h m g b 2$ and $h m g b 3$ expression patterns in dogfish testis may favor a better definition of the role of HMGB proteins during spermatogenesis and, more precisely, during spermatogonial proliferation.

MCM members are highly conserved DNA helicases involved in the $\mathrm{S}$ phase of cell cycle for many cell types in many species (Edwards et al. 2002, Sakwe et al. 2007). Those proteins are expressed by proliferative cells in response to the activation of ERK/MAPK signaling (Bruemmer et al. 2003). From zebrafish to mouse, MCM members are involved in the differentiation and proliferation of various tissue types during embryogenesis and juvenile development (Ryu \& Driever 2006, Swiech et al. 2007). In gonads, MCM proteins 2, 6, and 7 seem to be engaged in the regulation of transcription and/or chromatin remodeling during mouse oogenesis (Swiech et al. 2007), and MCM5 may be involved in the meiotic recombination pathway in Drosophila (Lake et al. 2007). A testis-specific expression pattern has been reported for MCM7 in the rat (Com et al. 2006) and fathead minnow, with Mcm 2-7 proteins being detected in mature testis (Martyniuka \& Alvarez 2013). In our study, mcm6 had a testis-specific expression and transcripts were observed in proliferating and differentiating spermatogonia, which is comparable with MCM7 protein expression in rat spermatogonia (Com et al. 2006). However, ISH did not evidence transcripts in meiotic cells, even if the results of PCR showed expression in the meiotic zone. Further studies on MCM members in $S$. canicula are needed to better understand the evolution of their function during spermatogenesis. It is interesting to note that our study showed that transcripts of these two types of factors involved in replication, HMGB and MCM, were not observed in spermatogonia $A_{s}$ and $A_{p}$. This could be related to their previously reported low replication activity (Loppion et al. 2008).

\section{Spermatogonial markers seem well conserved among vertebrates}

Spermatogonia subpopulations were well described in various species on the basis of morphological criteria (De Rooij \& Russell 2000, Leal et al. 2009) and their molecular characterization is continuously improving (Costa et al. 2012, for review, Nagano \& Yeh (2013)). However, the identification of spermatogonial markers in teleostean fish lags behind that of mammalians and is generally limited to one or two markers per studied
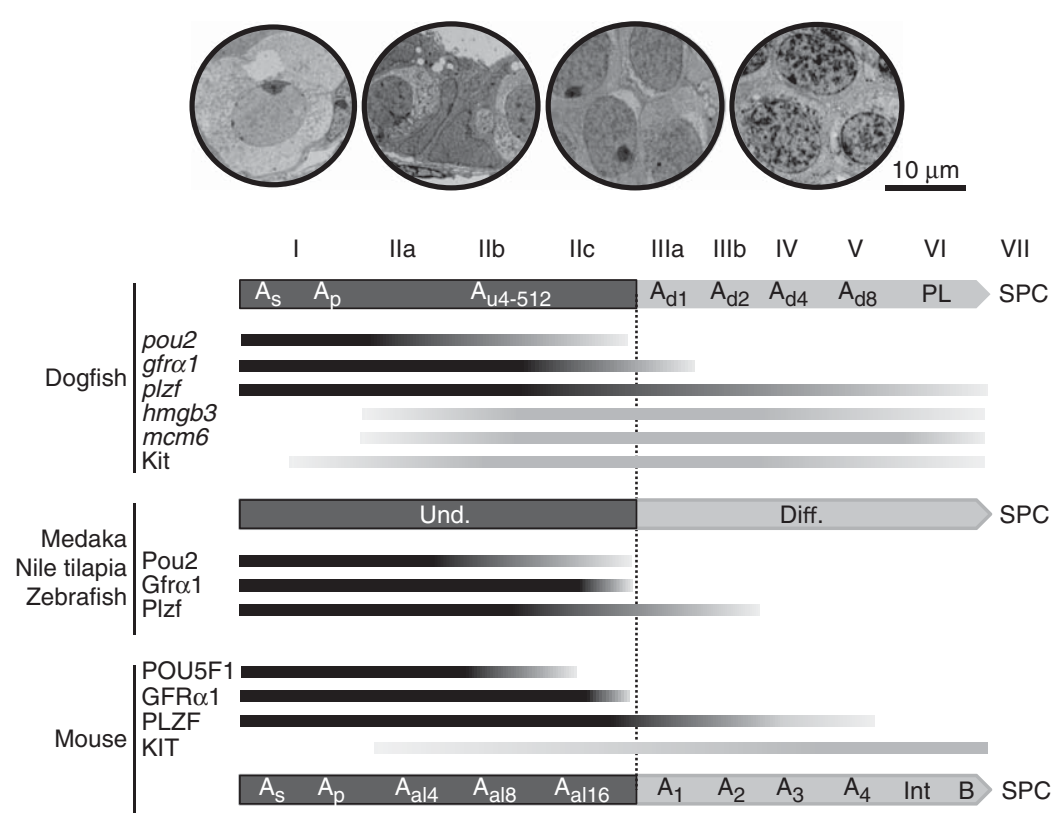

Figure 7 Evolution of the expression pattern of spermatogonial markers in Osteichthyes and Chondrichthyes. The protein expression patterns (bars) reported in mice for GFR $\alpha 1$, PLZF (Suzuki et al. 2009), C-KIT (Tokuda et al. 2006), and POU5F1 (Wu et al. 2010), in medaka for Pou2 (Sanchez-Sanchez et al. 2010), in zebrafish for Plzf (Ozaki et al. 2011) and in tilapia for Gfra1 (Lacerda et al. 2013) were compared with transcript expression in dogfish (pou2, gfr 1, plzf, hmgb3, and mcm6) and C-kit protein expression pattern (Loppion et al. 2008). The expression patterns of genes preferentially expressed in undifferentiated or differentiating spermatogonia are indicated with black and gray bars respectively. Similarly, spermatogonial subpopulations were subdivided into undifferentiated spermatogonia (und.) including spermatogonia $A_{s} A_{p}$, and $A_{u 4-512}$ in dogfish and $A_{s}, A_{p}$, and $A_{a l}$ in mice (dark gray boxes), and differentiating spermatogonia (diff.) including spermatogonia $A_{d 1-4}$ and PL in dogfish and $A_{1-4}$, Int and $B$ in mice (light gray boxes). Electron micrographs illustrate different spermatogonial populations in dogfish: large spermatogonia with mottled chromatin located in the germinative zone (stage I), $A_{u}$ included in a single cell layer with Sertoli cells (stage IIc), $A_{d}$ arranged in two layers (stage $\mathrm{IIIb}$ ), and $\mathrm{A}_{\mathrm{d}}$ with increasing amounts of heterochromatin (stage IV). SPC, spermatocyte. 
species. Only three recent studies of teleosts have described the expression pattern of the classical molecular markers we chose in this study (SanchezSanchez et al. 2010, Ozaki et al. 2011, Lacerda et al. 2013). Pou2, known for its role in the induction of pluripotency (Tapia et al. 2012), and Gfra1, involved in SSC self-renewal in response to GDNF (Naughton et al. 2005), seem well conserved as markers of undifferentiated spermatogonia from Osteichthyes (mammals and teleosts) to Chondrichthyes. Plzf, responsible for the maintenance of their undifferentiated condition (Buaas et al. 2004, Costoya et al. 2004), always shows an expression in undifferentiated spermatogonia extending to differentiating spermatogonia in zebrafish (Ozaki et al. 2011) and even further in dogfish. On the other hand, hmgb2 and 3 seem preferentially expressed in differentiating spermatogonia in dogfish like c-Kit, a classical marker of differentiating spermatogonia in mammals.

Considering that a flexible SSC system exists at least in mice (Yoshida 2012), the cellular and molecular characterizations of the microenvironments, including the SSC niche, which controls spermatogonia behavior, remain a challenge. Therefore, species with polarized testis where the SSC niche is easy to locate are of particular interest. Recent data show potential germinal stem cells at the periphery of the gonad in teleostean fish and could present SSC niche structures distributed along a strip surrounding the gonad, like in zebrafish ovary (Beer \& Draper 2013), or in pools scattered over a gonadal surface, called germinal cradles in medaka ovary (Nakamura et al. 2010). Finally, these scattered pools can be isolated within the tunica albuginea as suggested by data shown in Nile tilapia testis (Lacerda et al. 2013). The germinal zone seems well conserved in all these models harboring a cystic organization despite differences in term of distribution. Considering the niche conservation and other practical aspects (large size and easy isolation), the germinal zone of dogfish testis is a valuable model, which needs to be investigated further.

As a conclusion, we have shown that both GFR $\alpha 1$ and POU2/POU5F1 are evolutionary conserved factors expressed in the niche of the dogfish testis. Conversely, plzf presents a less restrictive expression pattern than in mammals with an expression in the niche but also during the differentiation phase of the dogfish testis. Also, new spermatogonial markers such as hmgb3 and mcm6 were found to be expressed in all spermatogonia except in $A_{s}$ and $A_{p}$ (Fig. 7). On the basis of the transcript expression of those factors, four different spermatogonial subpopulations were defined in the dogfish testis:

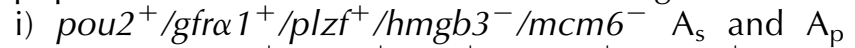
(stage I); ii) pou2 $2^{+} / g$ fr $1^{+} /$plzf $^{+} / \mathrm{hmgb3}^{+} / \mathrm{mcm6}^{+}$undifferentiated progenitor $A_{u}$ (stages Ila-IIc); iii) pou2 ${ }^{-}$/ gfr $1^{+} / p / z f^{+} / \mathrm{hmgb}^{+} / \mathrm{mcm}^{+}$differentiating spermato-

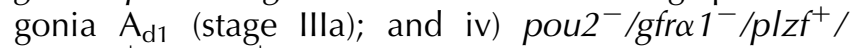
$\mathrm{hmgb3}^{+} / \mathrm{mcmb}^{+}$differentiated spermatogonia $\mathrm{A}_{\mathrm{d} 2}$ to
PL (stages IIIb-VIla). These proposed criteria now need to be confirmed at protein level, and further effort in functional studies will contribute to achieving a better understanding of the functional evolution of the SSC niche.

\section{Supplementary data}

This is linked to the online version of the paper at http://dx.doi. org/10.1530/REP-13-0316.

\section{Declaration of interest}

The authors declare that there is no conflict of interest that could be perceived as prejudicing the impartiality of the research reported.

\section{Funding}

This research was supported by the 'Conseil Régional de BasseNormandie' and 'Fonds Européen de Développement Régional' (PEPTISAN project certified by the competitiveness cluster 'Pole Mer Bretagne'). A Bosseboeuf PhD studies are supported by ANRT and Kelia (CIFRE grant).

\section{Acknowledgements}

The authors are grateful to Mr Faliguerho and Mr Lequenne of the 'Lycée Maritime et Aquacole de Cherbourg' (France) for capturing the dogfish specimens, the 'Cité de la Mer' (Cherbourg, France) and F Guyon of the 'Centre de Recherches en Environnement Côtier' (Luc-sur-mer, France) for the care given to the dogfish. The authors thank the members of the PHYLOFISH project (ANR- 2010-GENM-017) coordinated by J Bobe and $Y$ Guiguen for providing some of the sequences used in the present analysis. They also thank B Adeline for the preparation of the histological material and to Christophe Joubel for the English proofreading.

\section{References}

Airaksinen MS, Holm L \& Hätinen T 2006 Evolution of the GDNF family ligands and receptors. Brain, Behavior and Evolution 68 181-190. (doi:10.1159/000094087)

Ballow D, Meistrich ML, Matzuk M \& Rajkovic A 2006 Sohlh1 is essential for spermatogonial differentiation. Developmental Biology 294 161-167. (doi:10.1016/j.ydbio.2006.02.027)

Beer RL \& Draper BW 2013 Nanos3 maintains germline stem cells and expression of the conserved germline stem cell gene nanos2 in the zebrafish ovary. Developmental Biology 374 308-318. (doi:10.1016/ j.ydbio.2012.12.003)

Bhartiya D, Kasiviswanathan S, Unni SK, Pethe P, Dhabalia JV, Patwardhan S \& Tongaonkar HB 2010 Newer insights into premeiotic development of germ cells in adult human testis using Oct-4 as a stem cell marker. Journal of Histochemistry and Cytochemistry 58 1093-1106. (doi:10.1369/jhc.2010.956870)

Bruemmer D, Yin F, Liu J, Kiyono T, Fleck E, Van Herle AJ \& Law RE 2003 Expression of minichromosome maintenance proteins in vascular smooth muscle cells is ERK/MAPK dependent. Experimental Cell Research 290 28-37. (doi:10.1016/S0014-4827(03)00311-2) 
Buaas FW, Kirsh AL, Sharma M, McLean DJ, Morris JL, Griswold MD, de Rooij DG \& Braun RE 2004 Plzf is required in adult male germ cells for stem cell self-renewal. Nature Genetics 36 647-652. (doi:10.1038/ng1366)

Catena R, Escoffier E, Caron C, Khochbin S, Martianov I \& Davidson I 2009 Hmgb4, a novel member of the HMGB family, is preferentially expressed in the mouse testis and localizes to the basal pole of elongated spermatids. Biology of Reproduction 80 358-366. (doi:10.1095/ biolreprod.108.070243)

Chiarini-Garcia H, Raymer AM \& Russell LD 2003 Non-random distribution of spermatogonia in rats: evidence of niches in the seminiferous tubules. Reproduction 126 669-680. (doi:10.1530/rep.0. 1260669)

Com E, Rolland AD, Guerrois M, Aubry F, Jegou B, Vallet-Erdtmann V \& Pineau C 2006 Identification, molecular cloning, and cellular distribution of the rat homolog of minichromosome maintenance protein 7 (MCM7) in the rat testis. Molecular Reproduction and Development 73 866-877. (doi:10.1002/mrd.20453)

Coolen M, Sauka-Spengler T, Nicolle D, Le-Mentec C, Lallemand Y, Da Silva C, Plouhinec JL, Robert B, Wincker P, Shi DL et al. 2007 Evolution of axis specification mechanisms in jawed vertebrates: insights from a chondrichthyan. PLOS ONE 2 e374. (doi:10.1371/journal.pone. 0000374)

Costa GM, Avelar GF, Rezende-Neto JV, Campos-Junior PH, Lacerda SM, Andrade BS, Thomé RG, Hofmann MC \& Franca LR 2012 Spermatogonial stem cell markers and niche in equids. PLOS ONE 7 e44091. (doi:10.1371/journal.pone.0044091)

Costoya JA, Hobbs RM, Barna M, Cattoretti G, Manova K, Sukhwani M, Orwig KE, Wolgemuth DJ \& Pandolfi PP 2004 Essential role of Plzf in maintenance of spermatogonial stem cells. Nature Genetics 36 653-659. (doi:10.1038/ng1367)

De Rooij DG \& Russell LD 2000 All you wanted to know about spermatogonia but were afraid to ask. Journal of Andrology 21 776-798.

Edwards MC, Tutter AV, Cvetic C, Gilbert CH, Prokhorova TA \& Walter JC 2002 MCM2-7 complexes bind chromatin in a distributed pattern surrounding the origin recognition complex in xenopus egg extracts. Journal of Biological Chemistry 277 33049-33057. (doi:10.1074/ jbc.M204438200)

Encinas G, Zogbi C \& Stumpp T 2012 Detection of four germ cell markers in rats during testis morphogenesis: differences and similarities with mice. Cells, Tissues, Organs 195 443-455. (doi:10.1159/000329245)

Feng LX, Ravindranath N \& Dym M 2000 Stem cell factor/c-kit up-regulates cyclin $\mathrm{d} 3$ and promotes cell cycle progression via the phosphoinositide $3-k i n a s e / p 70$ s6 kinase pathway in spermatogoniaprogression via the phosphoinositide 3-kinase/p70 s6 kinase pathway in spermatogonia. Journal of Biological Chemistry 275 25572-25576. (doi:10.1074/jbc. M002218200)

Filipponi D, Hobbs RM, Ottolenghi S, Rossi P, Jannini EA, Pandolfi PP \& Dolci S 2007 Repression of kit expression by Plzf in germ cells. Molecular and Cellular Biology 27 6770-6781. (doi:10.1128/MCB. 00479-07)

Frankenberg S \& Renfree MB 2013 On the origin of POU5F1. BMC Biology 11 56-68. (doi:10.1186/1741-7007-11-56)

Frankenberg S, Pask A \& Renfree MB 2010 The evolution of class V POU domain transcription factors in vertebrates and their characterisation in a marsupial. Developmental Biology 337 162-170. (doi:10.1016/j.ydbio. 2009.10.017)

Hermann BP, Sukhwani M, Simorangkir DR, Chu T, Plant TM \& Orwig KE 2009 Molecular dissection of the male germ cell lineage identifies putative spermatogonial stem cells in rhesus macaques. Human Reproduction 24 1704-1716. (doi:10.1093/humrep/dep073)

Hermann BP, Sukhwani M, Hansel MC \& Orwig KE 2010 Spermatogonial stem cells in higher primates: are there differences from those in rodents? Reproduction 139 479-493. (doi:10.1530/REP-09-0255)

Hobbs RM, Seandel M, Falciatori I, Rafi S \& Pandolfi PP 2010 Plzf regulates germline progenitor self-renewal by opposing mTORC1. Cell 142 468-479. (doi:10.1016/j.cell.2010.06.041)

Holstein AF 1969 On the problem of the local control of the spermatogenesis of the spiny dogfish (Squalus acanthias L.). Zeitschriftfür Zellforschung 93 265-281. (doi:10.1007/BF00336694)

Joti P, Ghosh-Roy A \& Ray K 2011 Dynein light chain 1 functions in somatic cyst cells regulate spermatogonial divisions in Drosophila. Scientific Reports 1 173-182. (doi:10.1038/srep00173)
King BL, Gillis A, Carlisle HR \& Dahn RD 2011 A natural deletion of the HoxC cluster in elasmobranch fishes. Science 334 1517-1520. (doi:10.1126/science.1210912)

Kokkinaki M, Lee TP, He Z, Jiang J, Golestaneh N, Hofmann MC, Chan WY \& Dym M 2010 Age affects gene expression in mouse spermatogonial progenitor cells. Reproduction 139 1011-1020. (doi:10.1530/REP-090566)

Kubota H, Avarbock MR \& Brinster RL 2004 Culture conditions and single growth factors affect fate determination of mouse spermatogonial stem cells. Biology of Reproduction 71 722-731. (doi:10.1095/biolreprod. 104.029207)

Lacerda SM, Costa GM, Da Silva MD, Almeida Campos-Junior PH, Segatelli TM, Peixoto MT, Resende RR \& De França LR 2013 Phenotypic characterization and in vitro propagation and transplantation of the Nile tilapia (Oreochromis niloticus) spermatogonial stem cells. General and Comparative Endocrinology 5 e10740.

Lake CM, Teeter K, Page SC, Nielsen R \& Hawley RS 2007 A genetic analysis of the Drosophila mcm5 gene defines a domain specifically required for meiotic recombination. Genetics 176 2151-2163. (doi:10.1534/genetics.107.073551)

Leal MC, Cardoso ER, Nobrega RH, Batlouni SR, Bogerd J, França LR \& Schulz RW 2009 Histological and stereological evaluation of zebrafish (Danio rerio) spermatogenesis with an emphasis on spermatogonial generations. Biology of Reproduction 81 177-187. (doi:10.1095/ biolreprod.109.076299)

Letunic I, Doerks T \& Bork P 2012 SMART 7: a recent updates to the protein domain annotation resource. Nucleic Acids Research 40 302-305. (doi:10.1093/nar/gkr931)

Livak KJ \& Schmittgen TD 2001 Analysis of relative gene expression data using real-time quantitative PCR and the $2^{-\Delta \Delta C t}$ method. Methods $\mathbf{2 5}$ 402-408. (doi:10.1006/meth.2001.1262)

Loir M \& Sourdaine P 1994 Testes cell: isolation and culture. Biochemistry and Molecular Biology of Fishes 3 249-272. (doi:10.1016/B978-0-44482033-4.50028-3)

Loir M, Sourdaine P, Mendis-Handagama SM \& Jégou B 1995 Cell-cell interactions in the testis of teleosts and elasmobranchs. Microscopy Research and Technique 32 533-552. (doi:10.1002/jemt.1070320606)

Loppion G, Crespel A, Martinez AS, Auvray P \& Sourdaine P 2008 Study of the potential spermatogonial stem cell compartment in dogfish testis, Scyliorhinus canicula L. Cell and Tissue Research 332 533-542. (doi:10.1007/s00441-008-0590-z)

Loppion G, Lavigne R, Pineau C, Auvray P \& Sourdaine P 2010 Proteomic analysis of the spermatogonial stem cell compartment in dogfish Scyliorhinus canicula L. Comparative Biochemistry and Physiology, Part D 5 157-164.

Malarkey CS \& Churchill MEA 2012 The high mobility group box: the ultimate utility player of a cell. Trends in Biochemical Sciences 37 553-562. (doi:10.1016/j.tibs.2012.09.003)

Martyniuka CJ \& Alvarez S 2013 Proteome analysis of the fathead minnow (Pimephales promelas) reproductive testes. Journal of Proteomics $\mathbf{7 9}$ 28-42. (doi:10.1016/j.jprot.2012.11.023)

Mohapatra C, Barman HK, Panda RP, Sunil K, Das V \& Mohanta R 2010 Cloning of cDNA and prediction of peptide structure of Plzf expressed in the spermatogonial cells of Labeo rohita. Marine Genomics 3 157-163. (doi:10.1016/j.margen.2010.09.002)

Moleri S, Cappellano G, Gaudenzi G, Cermenati S, Cotelli F, Homer DS \& Beltrame $\mathbf{M} 2010$ The HMGB protein gene family in zebrafish: evolution and embryonic expression patterns. Gene Expression Patterns 11 3-11. (doi:10.1016/j.gep.2010.08.006)

Nagano MC \& Yeh JR 2013 The identity and fate decision control of spermatogonial stem cells: where is the point of no return? Current Topics in Developmental Biology 102 61-95.

Nakagawa T, Sharma M, Nabeshima YI, Braun RE \& Yoshida S 2010 Functional hierarchy and reversibility within the murine spermatogenic stem cell compartment. Science 328 62-67. (doi:10.1126/science.1182868)

Nakamura S, Kobayashi K, Nishimura T, Higashijima SI \& Tanaka M 2010 Identification of germline stem cells in the ovary of the teleost medaka. Science 328 1561-1563. (doi:10.1126/science.1185473)

Naughton CK, Jain S, Strickland AM, Gupta A \& Milbrandt J 2005 Glial cell-line derived neurotrophic factor-mediated ret signaling regulates spermatogonial stem cell fate. Biology of Reproduction 74 314-321. (doi:10.1095/biolreprod.105.047365) 
Nemeth MJ, Kirby MR \& Bodine DM 2006 Hmgb3 regulates the balance between hematopoietic stem cell self-renewal and differentiation. PNAS 103 13783-13788. (doi:10.1073/pnas.0604006103)

Oatley JM \& Brinster RL 2008 Regulation of spermatogonial stem cell selfrenewal in mammals. Annual Review of Cell and Developmental Biology 24 263-286. (doi:10.1146/annurev.cellbio.24.110707.175355)

Ozaki Y, Saito K, Shinya M, Kawasaki T \& Sakai N 2011 Evaluation of sycp3, plzf and cyclin B3 expression and suitability as spermatogonia and spermatocyte markers in zebrafish. Gene Expression Patterns 11 300-315. (doi:10.1016/j.gep.2011.03.002)

Prabhu SM, Meistrich ML, McLaughlin EA, Roman SD, Wam S, Mendis S, Itman C \& Loveland KL 2006 Expression of c-Kit receptor mRNA and protein in the developing, adult and irradiated rodent testis. Reproduction 131 489-499. (doi:10.1530/rep.1.00968)

Quan FB, Kenigfest NB, Mazan S \& Tostivint H 2013 Molecular cloning of the cDNAs encoding three somatostatin variants in the dogfish (Scyliorhinus canicula). General and Comparative Endocrinology 180 1-6. (doi:10.1016/j.ygcen.2012.10.007)

Redon E, Bosseboeuf A, Rocancourt C, Da Silva C, Wincker P, Mazan S \& Sourdaine P 2010 Stage-specific gene expression during spermatogenesis in the dogfish (Scyliorhinus canicula). Reproduction 140 57-71. (doi:10.1530/REP-10-0021)

Ronfani L, Ferraguti M, Croci L, Ovitt CE, Scholer HR, Consalez GG \& Bianchi ME 2001 Reduced fertility and spermatogenesis defects in mice lacking chromosomal protein Hmgb2. Development 128 1265-1273.

Ryu S \& Driever W 2006 Minichromosome maintenance proteins as markers for proliferation zones during embryogenesis. Cell Cycle $\mathbf{5}$ 1140-1142. (doi:10.4161/cc.5.11.2779)

Sakwe AM, Nguyen T, Athnasopoulos V, Shire K \& Frappier L 2007 Identification and characterization of a novel component of the human minichromosome maintenance complex. Molecular and Cellular Biology 27 3044-3055. (doi:10.1128/MCB.02384-06)

Sanchez-Sanchez AV, Camp E, Garcia-Espana A, Leal-Tassias A \& Mullor JL 2010 Medaka Oct4 is expressed during early embryo development, and in primordial germ cells and adult gonads. Developmental Dynamics 239 672-679. (doi:10.1002/dvdy.22198)

Schofield R 1983 The stem cell system. Biomedicine \& Pharmacotherapy 37 375-380.

Schultz J, Milpets F, Bork P \& Ponting CP 1998 SMART: a simple modular architecture research tool; identification of signaling domains. PNAS 95 5857-5864. (doi:10.1073/pnas.95.11.5857)

Sheng XR \& Matunis E 2011 Live imaging of the Drosophila spermatogonial stem cell niche reveals novel mechanisms regulating germline stem cell output. Development 138 3367-3376. (doi:10.1242/dev.065797)

Stanley HP 1966 The structure and development of the seminiferous follicle in Scyliorhinus caniculus and Torpedo marmorata (Elasmobranchii). Zeitschriftür Zellforschung 75 453-468. (doi:10.1007/BF00336875)

Suzuki H, Sada A, Yoshida S \& Saga Y 2009 The heterogeneity of spermatogonia is revealed by their topology and expression of marker proteins including the germ cell-specific proteins Nanos2 and Nanos3. Developmental Biology 336 222-231. (doi:10.1016/j.ydbio.2009.10.002)

Swiech L, Kisiel K, Czolowska R, Zientarski M \& Borsuk E 2007 Accumulation and dynamics of proteins of the MCM family during mouse oogenesis and the first embryonic cell cycle. International Journal of Developmental Biology 51 283-295. (doi:10.1387/ijdb. 062239ls)

Tamura K, Peterson D, Peterson N, Strecher G, Nei M \& Kumar S 2011 MEGA5: molecular evolutionary genetics analysis using maximum likelihood, evolutionary distance, and maximum parsimony methods. Molecular Biology and Evolution 28 2731-2739. (doi:10.1093/molbev/ msr121)

Tan YY, Kodzius R, Tay BH, Brenner S \& Venkatesh B 2012 Sequencing and analysis of full-length cDNAs, $5^{\prime}$-ESTs and $3^{\prime}$-ESTs from a cartilaginous fish, the elephant shark (Callorhinchus milii). PLOS ONE 7 e47174. (doi:10.1371/journal.pone.0047174)

Tapia N, Reinhardt P, Duemmler A, Wu G, Arauzo-Bravo MJ, Esch D, Greber B, Cojocaru V, Rascon CA, Tazaki A et al. 2012 Reprogramming to pluripotency is an ancient trait of vertebrate Oct4 and Pou2 proteins. Nature Communications 3 1279-1290. (doi:10.1038/ncomms2229)

Tenenhaus Dann C, Alvarado AL, Molyneux LA, Denard BS, Carrers DL \& Porteus MH 2008 Spermatogonial stem cell self-renewal requires OCT4, a factor downregulated during retinoic acid-induced differentiation. Stem Cells 26 2928-2937. (doi:10.1634/stemcells.2008-0134)

Thompson JD, Higgins D \& Gibson T 1994 CLUSTAL W: improving sensitivity of progressive multiple sequence alignment through sequence weighting, position-specific gap penalties and weight matrix choice. Nucleic Acids Research 22 4673-4680. (doi:10.1093/nar/22. 22.4673)

Tokuda M, Kadokawa Y, Kurahashi H \& Marunouchi T 2006 CDH1 is a specific marker for undifferentiated spermatogonia in mouse testis. Biology of Reproduction 76 130-141. (doi:10.1095/biolreprod.106. 053181)

Venkatesh B, Kirkness EF, Loh YH, Halpern AL, Lee AP, Johnson J, Dandona N, Viswanathan LD, Tay A, Venter JC et al. 2007 Survey sequencing and comparative analysis of the elephant shark (Callorhinchus milii) genome. PLoS Biology 5 932-944. (doi:10.1371/journal. pbio.0050101)

Wu X, Oatley JM, Kaucher AV, Avarbock MR \& Brinster RL 2010 The POU domain transcription factor POU3F1 is an important intrinsic regulator of GDNF-induced survival and self-renewal of mouse spermatogonial stem cells. Biology of Reproduction 82 1103-1111. (doi:10.1095/biolreprod. 109.083097)

Yoshida S 2012 Elucidating the identity and behavior of spermatogenic stem cells in the mouse testis. Reproduction 144 293-302. (doi:10.1530/REP11-0320)

Zetterstrom C, Strand M \& Soder O 2006 The high mobility group box chromosomal protein 1 is expressed in the human and rat testis where it may function as an antibacterial factor. Human Reproduction 21 2801-2809. (doi:10.1093/humrep/del256)

Received 17 July 2013

First decision 15 August 2013

Revised manuscript received 19 September 2013

Accepted 8 October 2013 